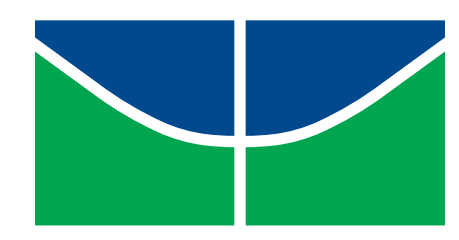

\author{
Universidade de Brasília \\ Instituto de Ciências Exatas \\ Departamento de Matemática
}

\title{
PRATICANDO ESTATÍSTICA NO ENSINO MÉDIO
}

\author{
por \\ MARCIO MELO FREITAS
}

Brasília, 2016 
MARCIO MELO FREITAS

\section{PRATICANDO ESTATÍSTICA NO ENSINO MÉDIO}

Dissertação apresentada ao Departamento de Matemática da Universidade de Brasília, como parte dos requisitos para a obtenção do grau de

\section{Mestre}

Orientador: Prof. Dr. Helder de Carvalho Matos

Brasilia

2016 
Universidade de Brasília

Instituto de Ciências Exatas

Departamento de Matemática

\section{PRATICANDO ESTATÍSTICA NO ENSINO MÉDIO}

por

\section{MARCIO MELO FREITAS ${ }^{1}$}

Dissertação apresentada ao Departamento de Matemática da Universidade de Brasília, como parte dos requisitos para obtenção do grau de

\section{MESTRE EM MATEMÁTICA}

Brasília, 17 de junho de 2016.

Comissão Examinadora:

Prof. Dr. Helder de Carvalho Matos - Orientador (MAT/UnB)

Prof. Dr. Raimundo de Araújo Bastos Júnior - Membro (MAT/UnB)

Prof. Dr. Raul Moreira Behs - Colégio Militar de Brasília/DF

(Membro)

${ }^{1} \mathrm{O}$ autor foi bolsista do CAPES durante a elaboração deste trabalho. 


\section{Mensagem}

"Ninguém caminha sem aprender a caminhar, sem aprender a fazer o caminho caminhando, refazendo e retocando o sonho pelo qual se pôs a caminhar". Paulo Freire 


\section{Agradecimentos}

Nesse momento tão especial de minha vida, eu não poderia deixar de lembrar daqueles que fizeram parte dela, principalmente, nestes dois últimos anos, em que compartilhamos alegrias e angústias durante os estudos. Agradeço, primeiramente, a Deus pelo dom da vida, da sabedoria e pelas infinitas bênçãos e alegrias concedidas durante esses dois anos de estudos e dedicação. Agradeço aos meus familiares, pai, mãe, esposa, filhas, enteados e irmãos pelo apoio incondicional e compreensão em razão da minha ausência durante todo esse período. Aos meus colegas e amigos de PROFMAT, um sentimento de gratidão e alegria por terem compartilhado várias manhãs de domingo e pela a disposição em me auxiliarem nos estudos. Uma grande homenagem ao meu e orientador, Dr. Helder de Carvalho Matos, pelos infinitos conselhos, ajudas, motivações e até pequenas broncas durante a realização desse trabalho, com as devidas exigências que muito contribuíram para o meu crescimento profissional. Muito obrigado Doutor por ter acreditado nas minhas ideias e pelo apoio a mim dispensado. Agradeço, ainda, ao corpo docente do Departamento de Matemática da Universidade de Brasília: Ary Vasconcelos, Helder Matos, Lineu Neto, Diego Marques, Angel Rodolfo Baigorri, Mauro Rabelo, Carlos Alberto, Kellcio Oliveira e o coordenador Rui Seimetz, pelo diferencial que fizeram em minha vida. Um especial agradecimento ao professor e amigo Rogério Ferreira dos Santos, por desenvolver este projeto juntamente comigo na escola em que laboramos. Enfim, agradeço a todos que de alguma forma contribuíram para que este sonho se tornasse realidade. 


\section{Resumo}

Este trabalho propõe como objeto de estudo analisar o processo de ensino aprendizagem de Estatística na etapa final da educação básica a partir de informações adquiridas pelos próprios alunos. Estas serão confrontadas com os parâmetros curriculares nacionais numa proposta interdisciplinar com as mais variadas áreas do conhecimento. Utilizou-se como procedimentos metodológicos a pesquisa quantitativa e qualitativa, a qual permitiu tabular, analisar e interpretar os dados colhidos baseados em questionários aplicados pelos alunos na própria comunidade escolar. Almeja-se, com este trabalho, que os profissionais envolvidos neste contexto dispensem um tratamento diferenciado ao ensino de estatística, no intuito de consolidar uma aprendizagem que dê sentido à realidade do aluno.

Palavras-chave: quantitativa, qualitativa, tabular, analisar, interpretar. 


\begin{abstract}
This work has as object of study to analyze the teaching process Statistical learning in the final stage of basic education from information acquired by the students - These will be faced with the curriculum guidelines in an interdisciplinary proposal with the most varied fields of knowledge. It was used as methodological procedures quantitative and qualitative research, which allowed tabulate, analyze and interpret the data collected based on questionnaires answered by students in their own school community. Aim, with this work, the professionals involved in this context dispense different treatment to statistical education in order to consolidate learning that makes sense to the student's reality.
\end{abstract}

Keywords: quantitative, qualitative, tabulate, analyze, interpret . 


\section{SUMÁRIO}

$\begin{array}{ll}\text { Introdução } & 1\end{array}$

1 PROBLEMATIZAÇÃO 3

1.1 Uso da Estatística através dos tempos . . . . . . . . . . . . . . 3

1.2 O que esperam do estudo da Estatística e Matemática . . . . . . . . . . 4

1.3 A rejeição à disciplina Matemática . . . . . . . . . . . . . . . . . . . 6

$1.4 \mathrm{O}$ que fazer? ....................... 6

2 FUNDAMENTAÇÃO METODOLÓGICA 8

2.1 Escolha da técnica . . . . . . . . . . . . . . . . . . . . 8

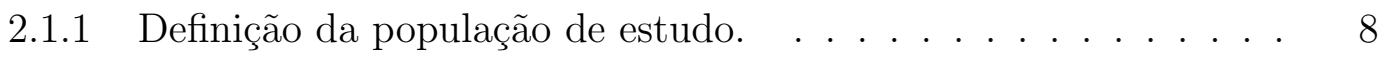

2.1.2 Tipos de Características. . . . . . . . . . . . . . . . 8

2.1.3 Tipos de Estudo . . . . . . . . . . . . . . . . . . . . 9 9

2.2 A Pesquisa como método . . . . . . . . . . . . . . . . 9

2.3 Delineamento do estudo: . . . . . . . . . . . . . . . . . . . . . . . . . 9

2.4 Selecionando os protagonistas e escolha do Tema: . . . . . . . . . . . . 10

2.4.1 Seleção dos participantes, criação dos grupos, com critério de inclusão e exclusão. . . . . . . . . . . . . . . . . . . . . . . 10

2.4.2 Escolha do tema com definição da população e fonte de estudo . 11

2.5 Criação de Questionários . . . . . . . . . . . . . . . . . . . . 12

2.6 Aplicação dos questionários . . . . . . . . . . . . . . . . . . . . . . 13

2.7 Tabulação dos dados . . . . . . . . . . . . . . . . . . . . . . . . . 13

2.8 Apresentação dos dados . . . . . . . . . . . . . . . . . . . . . . . 13

2.9 Utilização dos dados para o estudo da Estatística . . . . . . . . . . . . . 14

2.9.1 População, amostra e variável. . . . . . . . . . . . . . . . . . 14

2.9.2 As Medidas de tendência central . . . . . . . . . . . . . . . . . 14

2.10 Outros estudos . . . . . . . . . . . . . . . . . . . . . . . 15 
3 HORA DE PRATICAR... $\quad 16$

3.1 O começo - Criação de grupos e escolha do tema. . . . . . . . . . . 16

3.2 A criação do Questionário. . . . . . . . . . . . . . . . . 17

3.3 A aplicação do Questionário. . . . . . . . . . . . . . . . . . . . . . . 19

3.4 Lançamento dos dados. . . . . . . . . . . . . . . . . . . . . . . 19

3.5 Tabulação dos dados. . . . . . . . . . . . . . . . . . . . . . . 20

3.6 Gráficos de cada pergunta. . . . . . . . . . . . . . . . . . 22

3.7 Apresentação dos Trabalhos . . . . . . . . . . . . . . . . . . . . . . 42

3.8 Finalizando o trabalho com aulas sobre Medidas de Tendência Central

e Medidas de Dispersão. . . . . . . . . . . . . . . . . . . . . . . . . . . 42

3.8.1 Média Aritmética simples. . . . . . . . . . . . . . . . 43

3.8.2 Média ponderada. . . . . . . . . . . . . . . . . . 44

3.8.3 Média geométrica. . . . . . . . . . . . . . . . . . 44

3.8.4 Média harmônica. . . . . . . . . . . . . . . . . . . 45

3.8 Mediana. . . . . . . . . . . . . . . . . 46

3.8 .6 Moda. . . . . . . . . . . . . . . . . . . 46

3.8.7 Desvio médio. . . . . . . . . . . . . . . . . . 46

3.8 .8 Variância. . . . . . . . . . . . . . . . . 46

3.8 .9 Desvio padrão. . . . . . . . . . . . . . . . . . 47

3.9 Avaliação sem trauma . . . . . . . . . . . . . . . . . . . . 47

4 CONSIDERAÇÕES FINAIS $\quad 49$

REFERÊNCIAS $\quad 51$ 


\section{Lista de Figuras}

3.1 Questionário sobre Bullying . . . . . . . . . . . . . 18

3.2 Lançamento na Planilha Excel . . . . . . . . . . . . . . . . . . . . . 19

3.3 Final do lançamento do questionário . . . . . . . . . . . . . . 20

3.4 Preparação para tabulação dos dados lançados . . . . . . . . . . . . . . 21

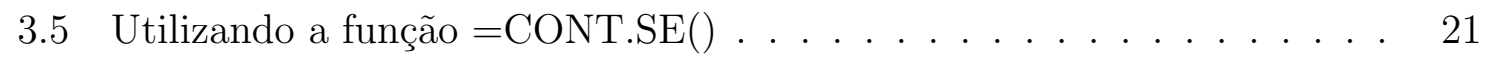

3.6 Qual a sua idade? . . . . . . . . . . . . . . . . . 22

3.7 Qual o seu sexo? . . . . . . . . . . . . . . . . . 23

3.8 Você já sofreu bullying? Se sim onde ocorreu? . . . . . . . . . . . . . . 24

3.9 Quando coagido, que atitude tomou ? . . . . . . . . . . 25

3.10 Dentro do seu grupo de amigos, alguém já sofreu bullying ? . . . . . . 26

3.11 Você já sofreu alguma violência, seja ela psicológica ou física em sua casa? . . . . . . . . . . . . . . . . . . . 27

3.12 Conhece quantas pessoas que já sofreram bullying ? . . . . . . . . . 28

3.13 Algum familiar seu já alegou sofrer bullying ou outra violência ? . . . . 29

3.14 Você já sofreu abuso sexual ? . . . . . . . . . . . . . . . . . . . 30

3.15 Já presenciou bullying em seu ambiente de trabalho ? . . . . . . . . . . 31

3.16 Você adquiriu fobia social por sofrer bullying ? . . . . . . . . . . . . 32

3.17 Qual a sua opção sexual ? . . . . . . . . . . . . . . . . . . . . . . . . . . . . . . . . 33

3.18 Já sofreu bullying devido a sua opção sexual ? . . . . . . . . . . . . . . 34

3.19 Tem algum amigo ou parente que já sofreu devido a opção sexual ? . . 35

3.20 Você considera o bullying um crime ? . . . . . . . . . . . . . . 36

3.21 Você acha que praticantes de bullying deviram ser punidos pela lei ? De

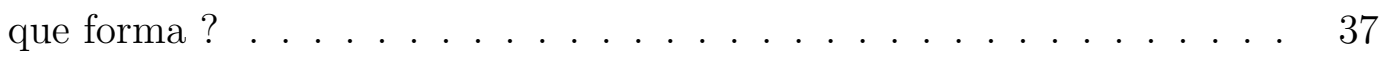

$3.22 \mathrm{Na}$ sua escola ou ambiente de trabalho existem palestras sobre esse tipo de assunto ? . . . . . . . . . . . . . . . . . . 38

3.23 Já tomou medidas violentas para com aquelas que praticaram alguma violência psicológica ou física com você ? . . . . . . . . . . . . . . . . . 39

3.24 Você acha que pessoas praticantes de bullying precisam de assistência de um profissional de saúde mental ? . . . . . . . . . . . . . . . . . . 40 
3.25 E você, já praticou bullying ? . . . . . . . . . . . . . . . . 41 


\section{Lista de Tabelas}

3.1 Qual a sua idade? . . . . . . . . . . . . . . . . . . . 22

3.2 Qual o seu sexo? . . . . . . . . . . . . . . . . 23

3.3 Você já sofreu bullying? Se sim onde ocorreu? . . . . . . . . . . . . . . 24

3.4 Quando coagido, que atitude tomou ?. . . . . . . . . . 25

3.5 Dentro do seu grupo de amigos, alguém já sofreu bullying ? . . . . . . 26

3.6 Você já sofreu alguma violência, seja ela psicológica ou física em sua casa? . . . . . . . . . . . . . . . . . 27

3.7 Conhece quantas pessoas que já sofreram bullying ? . . . . . . . . . 28

3.8 Algum familiar seu já alegou sofrer bullying ou outra violência ? . . . . 29

3.9 Você já sofreu abuso sexual ? . . . . . . . . . . . . . . . 30

3.10 Já presenciou bullying em seu ambiente de trabalho ? . . . . . . . . . . 31

3.11 Você adquiriu fobia social por sofrer bullying ? . . . . . . . . . . . 32

3.12 Qual a sua opção sexual ? . . . . . . . . . . . . . . . . . . . . . . . . . . . . . . . . . 33

3.13 Já sofreu bullying devido a sua opção sexual ? . . . . . . . . . . . . . . 34

3.14 Tem algum amigo ou parente que já sofreu devido a opção sexual ? . . 35

3.15 Você considera o bullying um crime ? . . . . . . . . . . . . . . 36

3.16 Você acha que praticantes de bullying deviram ser punidos pela lei ? De que forma.$\ldots \ldots \ldots$. . . . . . . . . . . . . 37

3.17 Na sua escola ou ambiente de trabalho existem palestras sobre esse tipo de assunto ? . . . . . . . . . . . . . . . . . . . . . 38

3.18 Já tomou medidas violentas para com aquelas que praticaram alguma violência psicológica ou física com você ? . . . . . . . . . . . . . 39

3.19 Você acha que pessoas praticantes de bullying precisam de assistência de um profissional de saúde mental ? . . . . . . . . . . . . . . . . . 40

3.20 E você, já praticou bullying ? . . . . . . . . . . . . . . . . . . 41 


\section{INTRODUÇÃO}

Não é de se admirar que discutir sobre Matemática sempre desperta atenção e traz grandes questionamentos, por se tratar de uma ciência, ao mesmo tempo, tão antiga quanto atual e fundamental tanto no ambiente escolar quanto no contexto mundial. O ensino da matemática marcado pela memorização de fórmulas, falta de questionamento por parte dos alunos e pela total inabilidade na formulação de conceitos, faz com que muitos acreditem que o estudo de diversos assuntos desta disciplina é inútil e está em um grau superior de compreensão, consoante (MACHADO [12], P.13, 2008): "Para grande parte das pessoas, a matemática permanece um tema obscuro, repleto de tecnicidades, virtualmente incompreensível, lugar por excelência das abstrações abstrusa".

A proposta desta pesquisa é analisar o processo da prática do ensino da Estatística $^{2}$ na disciplina Matemática com base nos Parâmetros Curriculares Nacionais.

A Matemática, embora seja utilizada no cotidiano de todos, de forma necessária e primordial, é considerada pela maioria das pessoas como disciplina de conteúdo difícil e sem efetiva utilização. Não há consciência de que se utiliza a matemática rotineiramente, nas necessidades primárias, nas profissões, em uma contagem, análise gráfica, notícias de finanças ou comparação entre produtos, mesmo não tendo proximidade efetiva com os números.

Ciente da falta de interesse de nossos alunos diante da matemática, a estatística, como ciência, atenderá bem aos nossos propósitos, pois a todo o momento podemos utilizar a matemática através dela para entender, planejar, experimentar, obter dados, organizá-los, resumi-los, analisá-los e interpretá-los e assim extrair conclusões.

A Estatística abrange muito mais do que o simples cálculo de uma média ou um traçado de gráficos. O volume de informações recebidas pela sociedade cotidi-

\footnotetext{
${ }^{2}$ Estatística é a ciência que se utiliza das teorias probabilísticas para explicar a frequência da ocorrência de eventos, tanto em estudos observacionais quanto em experimentos para modelar a aleatoriedade e a incerteza de forma a estimar ou possibilitar a previsão de fenômenos futuros, conforme o caso. A estatística é uma ciência que se dedica à coleta, análise e interpretação de dados.
} 
anamente confirma a necessidade do ensino da Estatística para análise e compreensão destas informações.

Em diversas pesquisas recorrem-se a métodos quantitativos e qualitativos representados por meio de gráficos e tabelas que, com efeito, são mais compreensíveis que a utilização dos números e fórmulas matemáticas. Assim os professores deverão lançar mão de práticas pedagógicas que favorecerão o melhor conhecimento deste conteúdo.

Renomados autores, dentre eles: Becker [1], 1993; Perrenoud [13], 1999 e Vasconcelos [16], 2003; constataram os benefícios da prática pedagógica juntamente com a teoria e esclareceram que "Inúmeros estudos têm surgido com o intuito de investigar a relação entre a prática pedagógica e a teoria que sustenta o trabalho docente". No presente estudo utilizar-se-á a prática Estatística como forma de auxiliar o discente a entender, interpretar e refletir as informações fornecidas pelas pesquisas, objetivando assim uma aprendizagem significativa.

Vale salientar que o professor possui papel fundamental não apenas no planejamento das tarefas, mas também na condução e envolvimento dos alunos, a fim de mantê-los, ao longo do tempo, interessados para que as questões a serem levantadas tornem-se esclarecedoras e estimulantes.

Cabe ressaltar, que ao trabalhar com os alunos em projetos durante as aulas de estatística, o próprio professor poderá desenvolver uma atitude investigativa em relação à sua prática. Significa dizer que, ao proporcionar situações de interesses dos alunos, o professor cria condições para avaliar sua atividade profissional e melhorá-la, aprimorando o conhecimento estatístico e didático, avaliando os alunos, relação Comunidade Escola e Escola Comunidade. Há que se destacar, outrossim, a importância da interdisciplinaridade (relação da sua disciplina com as demais).

Conforme destacado o objetivo deste, é mostrar que se utilizarmos a matemática de forma prática, pode-se estimular os alunos a apreciar a disciplina, o que será feito com a prática pedagógica da ciência Estatística. 


\section{Capítulo 1}

\section{PROBLEMATIZAÇÃO}

\subsection{Uso da Estatística através dos tempos \\ Um pouco de história ${ }^{1}$ :}

A origem da palavra Estatística está associada à palavra latina STATUS (Estado). Há indícios de que 3000 anos A.C. já se faziam censos na Babilônia, China e Egito e até mesmo o $4^{\circ}$ livro do Velho Testamento faz referência à uma instrução dada a Moisés, para que fizesse um levantamento dos homens de Israel que estivessem aptos para guerrear. Usualmente, estas informações eram utilizadas para a taxação de impostos ou para o alistamento militar. O Imperador César Augusto, por exemplo, ordenou que se fizesse o Censo de todo o Império Romano. A palavra CENSO é derivada da palavra CENSERE, que em Latim significa TAXAR. Em 1085, Guilherme, O Conquistador, solicitou um levantamento estatístico da Inglaterra, que deveria conter informações sobre terras, proprietários, uso da terra, empregados e animais. Os resultados deste censo foram publicados em 1086 no livro intitulado "Domesday Book" e serviram de base para o cálculo de impostos. Contudo, mesmo que a prática de coletar dados sobre colheitas, composição da população humana ou de animais, impostos, etc., fosse conhecida pelos egípcios, hebreus, caldeus e gregos, e se atribuam a Aristóteles cento e oitenta descrições de Estados, apenas no século XVII a Estatística passou a ser considerada disciplina autônoma, tendo como objetivo básico a descrição dos BENS do Estado. A palavra Estatística foi cunhada pelo acadêmico alemão Gottfried Achenwall (1719-1772), que foi um notável continuador dos estudos de Hermann Conrig (16061681). A escola alemã atingiu sua maturidade com A. L. Von Schlozer (1735-1809), mas sempre com ideias diferentes daquelas que fundamentaram a Estatística Moderna. Com algum exagero, pode-se dizer que o seu principal legado foi o termo STAATENKUNDE, que deu origem à designação atual. Na Enciclopédia Britânica, o verbete STATISTICS apareceu em 1797. Em contraposição à natureza eminentemente quali-

\footnotetext{
${ }^{1}$ Extraído de: http://www.ufscar.br/jcfogo/Estat_1/arquivos/Historia_da_Estatistica.pdf
} 
tativa da escola alemã, na Inglaterra do século XVII surgiram os aritméticos políticos, dentre os quais se destacaram John Graunt (1620-1674) e William Petty (1623-1687). Eles preocuparam-se com o estudo numérico dos fenômenos sociais e políticos, na busca de leis quantitativas que pudessem explicá-los. O estudo consistia essencialmente de exaustivas análises de nascimentos e mortes, realizadas através das Tábuas de Mortalidade, que deram origem às atuais tábuas usadas pelas companhias de seguros. Dessa forma, a escola dos aritméticos políticos pode ser considerada o berço da Demografia. Um de seus mais notáveis adeptos foi o pastor alemão Sussmilch (1707-1767), com o qual pode-se dizer que a Estatística aparece pela primeira vez como meio indutivo de investigação. Na última metade do século XIX, os alemães Helmert (1843-1917) e Wilhelm Lexis (1837-1914), o dinamarquês Thorvald Nicolai Thiele (1838-1910) e o inglês Francis Ysidro Edgeworth (1845-1926), obtiveram resultados extremamente valiosos para o desenvolvimento da Inferência Estatística, muitos dos quais só foram completamente compreendidos mais tarde. Contudo, o impulso decisivo deve-se a Karl Pearson (1857-1936), William S. Gosset (1876-1937) e, em especial, a Ronald A. Fisher (1890-1962).

\subsection{O que esperam do estudo da Estatística e Ma- temática}

O concluinte do ensino médio estuda a Estatística junto ao conteúdo da Matemática.

Nos Parâmetros Curriculares Nacionais do Ensino Médio - PCNEM [2] constam as competências indicadas na Base Nacional Comum para a área de Ciências da Natureza, Matemática e suas Tecnologias nele pretendem que os alunos nesse nível escolar desenvolvam habilidades básicas e competências específicas no aprendizado da Matemática e suas tecnologias relacionadas. O Ensino Médio é, estabelecido pela LDB $/ 96^{2}$, a etapa final da Educação Básica, completando o aprendizado iniciado no Ensino Fundamental. Os PCNs direcionam o aprendizado da Matemática a produzir conhecimentos efetivos com significados próprios, ele afirma que:

[...] na seção sobre O Sentido do aprendizado na área, uma proposta para o Ensino Médio que, sem ser profissionalizante, efetivamente propicie um aprendizado útil à vida e ao trabalho, no qual as informações, o conhecimento, as competências, as habilidades e os valores desenvolvidos sejam instrumentos reais de percepção, satisfação, interpretação, julgamento, atuação, desenvolvimento pessoal ou de aprendizado permanente, evitando tópicos cujos sentidos só possam ser compreendidos em outra etapa de escolaridade. PCNEM -Parâmetros Curriculares Nacionais Ensino Médio

\footnotetext{
${ }^{2}$ LDB - Lei de Diretrizes e Bases da Educação Nacional. Lei que disciplina a educação escolar, que se desenvolve, predominantemente, por meio do ensino, em instituições próprias. Última atualização através da LEI No 9.394, DE 20 DE DEZEMBRO DE 1996.
} 
Notem que os PCNEM orientam o ensino da matemática para um aprendizado efetivo com a utilização de conteúdos anteriores, sendo sempre pré-requisitos o conhecimento matemático de fases de estudos anteriores.

Os PCNEM evidenciam a utilização da matemática na prática, exigência das necessidades atuais, nele discorre que:

Os objetivos do Ensino Médio em cada área do conhecimento devem envolver, de forma combinada, o desenvolvimento de conhecimentos práticos, contextualizados, que respondam às necessidades da vida contemporânea, e o desenvolvimento de conhecimentos mais amplos e abstratos, que correspondam a uma cultura geral e a uma visão de mundo. Para a área das Ciências da Natureza, Matemática e Tecnologias, isto é particularmente verdadeiro, pois a crescente valorização do conhecimento e da capacidade de inovar demanda cidadãos capazes de aprender continuamente, para o que é essencial uma formação geral e não apenas um treinamento específico. PCNEM -Parâmetros Curriculares Nacionais Ensino Médio

Devemos acrescentar que o mundo contemporâneo é digital e todas as ciências utilizam as tecnologias a seu favor como forma de desenvolver suas habilidades. Hoje consideramos que quase todos dessa geração são nativos digitais e, por conseguinte tem o entendimento completo de seus equipamentos. Mas devemos ressaltar que os jovens basicamente utilizam seus apetrechos tecnológicos para a comunicação e diversão entre eles.

Entendemos que devemos aproveitar a utilização dessas tecnologias pelos alunos e fazer com que eles produzam informações, análises e julgamentos das ciências estudadas, criando com isso competências e habilidades para a compreensão da sua cidadania, do eu social, do eu profissional e de sua relação como o mundo globalizado em geral. Os PCNEM destacam:

Ao se denominar a área como sendo não só de Ciências e Matemática, mas também de suas Tecnologias, sinaliza-se claramente que, em cada uma de suas disciplinas, pretende-se promover competências e habilidades que sirvam para o exercício de intervenções e julgamentos práticos. Isto significa, por exemplo, o entendimento de equipamentos e de procedimentos técnicos, a obtenção e análise de informações, a avaliação de riscos e benefícios em processos tecnológicos, de um significado amplo para a cidadania e também para a vida profissional. 
Com esta compreensão, o aprendizado deve contribuir não só para o conhecimento técnico, mas também para uma cultura mais ampla, desenvolvendo meios para a interpretação de fatos naturais, a compreensão de procedimentos e equipamentos do cotidiano social e profissional, assim como para a articulação de uma visão do mundo natural e social. Deve propiciar a construção de compreensão dinâmica da nossa vivência material, de convívio harmônico com o mundo da informação, de entendimento histórico da vida social e produtiva, de percepção evolutiva da vida, do planeta e do cosmos, enfim, um aprendizado com caráter prático e crítico e uma participação no romance da cultura científica, ingrediente essencial da aventura humana. PCNEM -Parâmetros Curriculares Nacionais Ensino Médio

\subsection{A rejeição à disciplina Matemática}

Os objetivos a serem alcançados pelos PCNEM[2] são excelentes, mas a realidade dos professores de Matemática é outra, temos um alto índice de rejeição, o que torna o ensino da disciplina extremamente desafiante.

A rejeição à disciplina Matemática é perceptível através do simples convívio com os alunos, a falta de comprometimento é notória e seus reflexos estão nas notas baixas adquiridas desde o Ensino Fundamental até o término do ensino médio. O fato é que, por mais que seja necessária, a própria sociedade rejeita a Matemática, exaltando suas dificuldades e menosprezando sua importância, isto é, passou de um problema de relacionamento do aluno com a disciplina, para ser um grave problema cultural no Brasil, basta verificarmos os índices de proficiência em Matemática para constatarmos a veracidade do fato.

De fato a maior parte dos alunos ingressante na vida universitária não sabem a matemática básica, faltam o conhecimento dos conteúdos matemáticos escolares do Ensino Fundamental e Ensino Médio (CARVALHO; SAVIOLI,[3] 2013).

A consequência deste fato evidencia que o conteúdo ministrado pelo professor nessa ocasião causa desestímulo ao aluno e, por conseguinte o mesmo passa a não gostar da matemática. Outro fator que leva a rejeição da matemática é a falta de domínio do conteúdo por parte de alguns professores.

\subsection{O que fazer?}

Sendo assim, de que forma pode-se ajudar os alunos a verem com outros olhos a matemática? De que forma consegue-se estimulá-los, será que seria através da contextualização, ou com situações problemas do seu dia-a-dia ou incrementar com algo novo as aulas que por si só são cansativas e tediosas?

Como contribuição para a mudança desse processo, utilizar-se-á o método de resolução de problemas para desmistificar que a matemática é difícil. Inicialmente 
introduziremos uma questão problema de ordem social e através da estatística conduziremos nossos alunos de forma prática à solução deste.

Dessa forma espera-se que nossos alunos utilizem a estatística, selecionando informações, buscando métodos para sua solução e de modo geral tomem decisões para apresentar os resultados obtidos, lembrando que o professor tem papel importante nesse processo como mediador.

Esta pesquisa ficou estruturada conforme segue:

Primeiramente expôs-se o que motivou a verificação deste tema, quais problemas encontrados nos dias atuais e qual a relevância deste estudo.

A seguir apresentamos os aportes teóricos constantes nesta pesquisa que fizeram reflexão sobre o Ensino da Matemática embasando-o.

Seguindo, fez-se a opção pela criação de questionários, temas e formas de aplicação, com participação dos alunos, utilizando a metodologia quantitativa e delimitamos o universo de estudo.

Continuando, realiza-se a coleta e modelagem dos dados obtidos, os quais, a partir deles estuda-se a Estatística Descritiva através das médias, modas, medianas, separatrizes e através delas fez-se a análise e interpretação dos dados obtidos e assim buscaram-se as respostas para os problemas detectados.

Finalizando, volta-se ao problema inicial e reflete-se se com a metodologia de ensino utilizada para matemática e estatística conseguiu-se sucesso, se os alunos foram motivados o suficiente para se empenhar no estudo da estatística e, por conseguinte também da matemática. 


\section{Capítulo 2}

\section{FUNDAMENTAÇÃO METODOLÓGICA}

\subsection{Escolha da técnica}

Utilizaremos o Método da Pesquisa Estatística que compreende duas partes: o cálculo do tamanho da amostra e a análise estatística, responsáveis por responder perguntas de pesquisa. As técnicas de amostragem serão retratadas através da frequência de uma amostra representativa utilizando a Estatística nas seguintes fases do Estudo:

a) os alunos do $3^{\circ}$ ano do ensino médio deverão definir o objetivo do estudo;

b) após definição do objetivo deverão realizar o planejamento do estudo;

c) em seguida deverão coletar e analisar os dados;

d) por último, converter os resultados analisados em informações.

\subsubsection{Definição da população de estudo.}

Nessa etapa os alunos deverão decidir qual a população será alvo de seu estudo: quem é a população; que características e quantidades serão estudadas e analisadas.

\subsubsection{Tipos de Características.}

Quantitativas -serão descritas numericamente, podem ser discretas ou contínuas. Qualitativa - geralmente expressada por frases podem ser nominais ou ordinais. 


\subsubsection{Tipos de Estudo}

Descritivo - expresso geralmente através de gráficos, medidas ou tabelas;

Inferencial: estuda a partir dos dados coletados, o comportamento da população.

\subsection{A Pesquisa como método}

Para alcançar os objetivos deste trabalho, deve-se considerar as dificuldades de ensino-aprendizagem em Matemática destacados na problematização.

A Pesquisa como Método é imprescindível e importante para obtermos informações e conhecimentos científicos sobre determinado problema, é através dela que encontraremos meios para saná-los. Como Ludke e André [11](1986, p.02) afirmaram:

Para se realizar uma pesquisa é preciso promover o confronto entre os dados, as evidências, as informações coletadas sobre determinado assunto e o conhecimento teórico acumulado a respeito dele.

A pesquisa trás na prática, o confronto de realidades, permitindo a construção de conceitos, ideias e produções de conhecimentos, tudo isso atrelado ao grande incentivo que é dos alunos participarem ativamente sendo eles os protagonistas em todas as etapas do trabalho.

Durante o trabalho o professor será sempre mediador, orientando e sugerindo a melhor condução para o alcance dos objetivos desejados. Na apresentação do trabalho pelos alunos, o professor vai fazer algumas intervenções a respeito do tema, mostrando outro ramo da Estatística que orienta as tomadas de decisões a partir de uma amostra sobre um universo, a inferência estatística.

\subsection{Delineamento do estudo:}

O professor discorrerá sobre a importância desse estudo e da sua utilização no cotidiano de todos.

O professor apresentará diversos temas enfatizando seus pontos fracos e fortes que será objeto de estudo escolhido por um grupo, podendo cada grupo trazer outros temas para escolha e discussão. 


\subsection{Selecionando os protagonistas e escolha do Tema:}

\subsubsection{Seleção dos participantes, criação dos grupos, com critério de inclusão e exclusão.}

Para que o professor consiga dar uma melhor atenção aos alunos, a turma será dividida em grupos. Os grupos são heterogêneos de origem, por isso, devem-se superar as diversidades e adversidades, afinal de contas poucas tarefas podem ser feitas individualmente "Deus criou a adversidade nos homens" DESAFIOS[5], (p.200).

Para definir as equipes e grupos, respeitando suas diferenças, segue-se o conceito de grupos conforme Cohen e Fink [4](2003, p.62) conceituam: "pequenos conjuntos de pessoas que se encontram face a face, variando de mais de duas e em geral menos de 12 ou 15 indivíduos".

Somente separar em pequenos grupos não resolve o problema da diversidade das pessoas, temos que mostrar a eles que o trabalho em equipe requer aprendizagem e respeito ao outro, deve-se relevar os preconceitos e atitudes negativas em relação a temas, teorias e imagens.

O trabalho em equipe começa na pré-escola mostrando a cooperação, a divisão das tarefas, responsabilidades e o respeito aos próximos. No trabalho em equipe há o exercício de certas habilidades, pois enquanto ele aprende a defender sua escolha, avalia e ajuda a decidir sobre a escolha dos outros, ou seja, nesse trabalho, desde seu início o estudante vai treinar a discussão e a capacidade de ouvir posições contrárias respeitando opiniões diferentes, inclusive na divisão de tarefas. Este trabalho deveria ser mais frequente nas séries subsequentes em suas atividades acadêmicas. Outro fator importante no trabalho em equipe é a inclusão social provocada pelo professor em relação aos estudantes, pois, na vida, são tantas inclusões necessárias: de etnia, de gênero, cultural, de portadores de necessidades especiais, crianças de rua, o alcoólatra, os portadores de HIV, etc...

Respeitando as preocupações acima, passa-se a divisão da turma. Os grupos de trabalho serão divididos por sorteio, evitando a formação de grupos homogêneos e estimulando a convivência de alunos que não são amigos, pois no mercado de trabalho nem sempre você escolhe seus pares. Dessa forma pode-se acarretar uma série de atritos, mas isso é positivo, já que comprovadamente grupos homogêneos não apresentam vantagens pedagógicas.

Após a formação dos grupos, é salutar provocar os integrantes a dividirem as tarefas e proporcionar a todos a participação em cada uma delas, haja vista que a alternância dos parceiros nas tarefas traz a tona, em cada um, novas habilidades fazendo com que um integrante do grupo, mesmo tímido, possa se destacar e até chegar a ser líder. Isso ocorre quando reunimos pessoas diferentes.

O professor deverá acompanhar o planejamento de cada grupo, é muito 
importante lembrar aos grupos sobre o estabelecimento de metas e prazos para cada tarefa.

\subsubsection{Escolha do tema com definição da população e fonte de estudo}

Cada grupo deve escolher um tema para ser trabalhado. Apesar da escolha do tema ser um dos primeiros passos no desenvolvimento deste trabalho, não é simples decidi-lo, pois como ele é feito em equipe, cada componente tem a liberdade de escolher um tema e defendê-lo diante de seus colegas, assuntos para pesquisar não faltam, isso pode gerar bastante polêmica, pois poderão surgir temas afins ou totalmente distintos, desta forma a escolha é de fundamental importância. Para Marconi e Lakatos[9] (2008, p.220) tema é o assunto que se deseja estudar e pesquisar. O professor tem papel importante nesse momento, estimulando-os a selecionar um assunto de acordo com suas inclinações e aptidões, levando em consideração temas socioculturais atuais.

A partir do momento que o tema for escolhido pela equipe, este deverá ser estudado por todos, para que o trabalho tenha unidade, e seus resultados sejam o mais fiel possível à realidade pesquisada.

Como o tema é de livre escolha da equipe, normalmente procura-se tema com o qual se tenha maior afinidade, isso deve proporcionar experiências mais positivas, prazerosas e enriquecedoras, contribuindo ainda mais com o aprendizado do estudante.

Ao decidir pelo tema o grupo deverá elencar os motivos que justifiquem a escolha deste. As fontes para escolha do assunto provavelmente serão originadas de estudos ou de leituras ou até mesmo de observação de fatos relacionados no seu cotidiano.

O professor deverá orientá-los a constatar um problema relacionado ao tema cujo objetivo ao final do trabalho será a resolução ou o esclarecimento deste, sendo assim o problema será o ponto de partida do trabalho. Desse modo é muito importante a formulação do problema, pois dela dependerá o desenvolvimento do trabalho.

Para Marconi e Lakatos[9] (2008, p.129), o problema compreende um enunciado explicitado de forma clara, compreensível e operacional, para o qual a solução pode ser obtida por meio de uma pesquisa, por outro lado Gil[7] (1991, p.49) declara que, problema é qualquer questão não resolvida e que é objeto de discussão, em qualquer domínio do conhecimento. Podemos inferir, dessa forma, que o problema deverá referir-se ao tema mostrando uma questão que necessita de discussão, solução, investigação ou decisão.

Quanto à população e fonte de estudo, destaca-se que chamamos de população o todo, o universo de nossa pesquisa que possuam as mesmas características definidas em nosso estudo, e amostra é parte da população selecionada a partir de uma regra. 
Como a pesquisa será feita por menores, normalmente, reduz-se nossa população à Comunidade Escolar em que se encontram, podendo essa pesquisa alcançar, além da Comunidade Escolar, parentes e amigos do acadêmico, o Comércio Local, outras escolas e etc., porém, com a permissão dos responsáveis.

Quanto às amostras, utilizaremos as amostras probabilísticas casuais simples, quando cada elemento da população tem a mesma oportunidade de inclusão na amostra ou por agrupamento, quando reunimos amostras representativas de uma população.

\subsection{Criação de Questionários}

Para a confecção do questionário, utilizaremos a Pesquisa Aplicada, segundo Silva e Menezes[14] (2000, p.20) ela objetiva gerar conhecimentos para aplicação prática dirigidos à solução de problemas específicos. Envolve verdades e interesses locais. Utilizaremos também a Pesquisa Quantitativa e ainda conforme Silva e Menezes[14] (2000, p.20) ela considera que tudo pode ser quantificável, o que significa traduzir em números opiniões e informações para classificá-los e analisá-los. Requer o uso de recursos e de técnicas estatísticas (percentagem, média, moda, mediana, desvio padrão, coeficiente de correlação, análise de regressão etc). Utilizaremos ainda a Pesquisa Descritiva que segundo Gil,[7] (2002, p. 42) ela visa descrever as características de determinada população ou fenômeno ou o estabelecimento de relações entre variáveis. Envolvem o uso de técnicas padronizadas de coleta de dados: questionário e observação sistemática. Assume, em geral, a forma de Levantamento. Lembrando que a Pesquisa Aplicada é do ponto de vista da natureza da pesquisa, a Pesquisa Quantitativa é do ponto de vista da forma de abordagem do problema da pesquisa e a Pesquisa Descritiva é do ponto de vista dos objetivos da pesquisa.

O questionário será composto de uma série de perguntas ordenadas que deverão ser respondidas pelo pesquisado, e devem ser objetivas, com perguntas reduzidas e com instruções para respostas, sem tendenciá-las. As instruções devem ser explicativas para facilitar o preenchimento do questionário, ressaltando a finalidade de sua aplicação bem como a importância do pesquisado ao respondê-lo.

O questionário deverá conter perguntas fechadas, com apenas duas escolhas, ou múltipla escolha, que são perguntas fechadas com uma série de respostas possíveis.

- O questionário deverá ser construído em blocos temáticos obedecendo a uma ordem lógica na elaboração das perguntas;

- A redação das perguntas deverá ser feita em linguagem compreensível ao pesquisado. A linguagem deverá ser acessível ao entendimento da média da população 
estudada. A formulação das perguntas deverá evitar a possibilidade de interpretação dúbia, sugerir ou induzir a resposta;

- Cada pergunta deverá focar apenas uma questão para ser analisada pelo informante;

- O questionário deverá conter apenas as perguntas relacionadas aos objetivos do trabalho. Devem ser evitadas perguntas que, de antemão, já se sabe que não serão respondidas com honestidade.

\subsection{Aplicação dos questionários}

Após a confecção dos instrumentos, inicia-se a coleta de dados.

Como já dissemos anteriormente a pesquisa será feita por menores, normalmente, reduzimos nossa população à Comunidade Escolar em que se encontram, podendo essa pesquisa alcançar, além da Comunidade Escolar, parentes e amigos do acadêmico, o Comércio Local, outras escolas e etc., porém, com a permissão dos responsáveis, o mesmo ocorre na aplicação do questionário.

\subsection{Tabulação dos dados}

Após a coleta de dados, é necessária a tabulação destes e o faremos através de instrumentos manuais ou computacionais, no caso do instrumento ser manual, utilizaremos o princípio fundamental da contagem formando tabelas, no caso do instrumento ser computacional, utilizaremos as planilhas eletrônicas e suas funções matemáticas e estatísticas.

Qualquer forma de tabulação utilizada nos ajudará na interpretação e análise dos dados coletados.

\subsection{Apresentação dos dados}

Nessa fase os dados já foram tabulados, organizados e são apresentados conforme o método escolhido na etapa anterior. Chegou a hora de interpretar e analisar esses dados, essa análise deverá ser feita para confirmar ou rejeitar a hipótese problemática do trabalho. 


\subsection{Utilização dos dados para o estudo da Estatística}

\subsubsection{População, amostra e variável.}

Nesse momento o professor deverá definir população (ou Universo) e amostra apontando em cada trabalho dos alunos o conjunto que compartilham de pelo menos uma característica comum, por isso o universo utilizado por cada um deles. No caso da amostra, é importante destacar que pelo universo ser finito e bastante razoável quantitativamente, em muitos casos foram utilizados o próprio universo como amostra. Vale ressaltar que a amostra nem sempre é o próprio universo.

Utilizaremos uma amostra casual (probabilística), sendo assim, pode-se definir um número para cada elemento para que seja selecionado. A amostragem aleatória pode ser segundo LEVIN[10] (1987, p.28): aleatória simples - os elementos são escolhidos através do uso de tabela de números aleatórios; sistemática - é definida por intervalos fixos; estratificada - a população é dividida em grupos e método de conglomerados - a amostra é uma unidade representativa da população. Para atingirmos os objetivos pedagogicamente, utilizaremos a amostragem aleatória simples ou casual simples pela facilidade de sua compreensão e uso.

Para o estudo estatístico utilizaremos a variável quantitativa discreta, pois os resultados possíveis são numéricos e facilmente medidos, sendo assim, seus valores são enumerados e podem ser contados.

\subsubsection{As Medidas de tendência central}

A partir dos dados enumerados e tabulados, o professor deverá ensinar seus alunos a extrair as médias, aritméticas simples e ponderadas, geométricas e harmônicas. Mostrar aos seus alunos a efetiva utilização das medidas de tendência central e o que ela nos aponta em relação a cada trabalho. Os gráficos e tabelas confeccionados pelos alunos contêm diversos números que determinam um conjunto de dados, dessas informações retiraremos valores que representam este conjunto, esses valores são as Medidas de Tendência Central ou de Centralidade.

Utiliza-se o cálculo da Média Aritmética com frequência, pois seu cálculo direciona as ideias contidas em determinados estudos, a Média Ponderada é calculada quando se trata de números que se repetem (pesos) ou que tenham uma importância diferenciada. A Moda é a medida de posição que aponta o valor observado com maior frequência e a mediana indica exatamente o valor central que divide o conjunto de dados organizados (crescente ou decrescente), caso a amostra apresente uma quantidade par de dados, sua mediana será determinada pela média dos dois valores centrais da amostra.

Notem que os valores encontrados na Média Aritmética, na moda e na 
mediana são únicos e tendem identificar a posição central dentro do conjunto estudado.

Há de se destacar que as medidas de tendência central têm problemas quando trabalhamos com valores extremos, valores estes extremamente superiores aos demais de uma amostra.

\subsection{Outros estudos}

É conveniente estender os estudos estatísticos, mostrando que pode-se dividir um conjunto de dados em classes e as mesmas serem representadas por gráficos chamados histogramas e que a união dos seus pontos médios cria um polígono de frequência.

As medidas de tendência central trazem valor central, mas não discorrem sobre como estão se comportando os dados em torno da média, para isso utilizaremos as medidas de dispersão: a variância e o desvio padrão.

A variância estuda o quanto está distante cada valor desse conjunto em relação ao valor central, quanto maior a variância, mais distante os valores estão da média e, por conseguinte, quanto menor a variância, mais próximo os valores estão da média. A variância é muito influenciada por valores que estão muito distantes da média, então estudaremos outra medida de dispersão que é o desvio padrão que calcula a diferença de cada valor em relação à média. Ambas medidas de dispersão necessárias para correção de erros discrepantes encontrados na média. 


\section{Capítulo 3}

\section{HORA DE PRATICAR...}

\subsection{O começo - Criação de grupos e escolha do tema.}

Para exemplificar, trouxemos o projeto desenvolvido pelos alunos de terceiro ano do ensino médio de um colégio particular. Dentre outros escolhemos o projeto cujo tema é bastante atual e recorrente nos meios sociais em que estão inseridos, "Bullying". Este grupo de alunos contém cinco componentes e desenvolveram um questionário com vinte questões pertinentes ao tema. Lembrando que este grupo, assim como os demais e seus referidos temas, aprofundaram seus conhecimentos, pesquisando, discutindo e estudando o conteúdo abordado por diversos autores e mídias, inclusive pedindo ajuda a professores de diferentes conteúdos, enriquecendo seus conhecimentos e valores internos de cada um. Só para citar a diversidade de temas desenvolvidos pelos alunos deste terceiro ano do ensino médio, temos:

1. Bullying - é uma situação caracterizada por atos agressivos verbais ou físicos de maneira repetitiva por parte de um ou mais alunos contra um ou mais colegas. O termo inglês refere-se ao verbo "ameaçar, intimidar".

2. Preconceito - na atualidade se comentam sobre vários temas, alguns deles são preconceito, drogas e gravidez na adolescência.

3. Gravidez na Adolescência - a adolescência é uma fase de descobertas para os jovens, sendo que esta fase pode ser de descobrimentos tanto positivos quanto negativos, ou seja, é por meio destas experiências que eles formarão opiniões futuras, na fase adulta.

4. Política - o termo política tem sua origem do grego "Politiké" que se refere as ações tomadas levando em conta, a cidade, um determinado conjunto de habitantes ou pessoas, a população . 
Lembramos que todos os temas foram criados e discutidos pelos integrantes de cada grupo, chegando ao consenso entre eles.

\subsection{A criação do Questionário.}

Com os grupos criados e tema discutido, é hora de formular as perguntas do questionário.

A título de organização didática, elegemos, sem menosprezar os outros grupos e temas, o grupo que tratou do tema "Bullying" para nos acompanhar na demonstração prática do trabalho.

Abaixo relacionaremos as perguntas confeccionadas pelos alunos à respeito do tema "Bullying":

Para não incorrermos em erro de direitos autorais, não citaremos os nomes dos alunos nem o colégio em que foi aplicada esta metodologia de trabalho. Abaixo na íntegra o questionário criado pelos alunos sobre "Bullying" na Figura 3.1. 


\section{Colégio XXXXXXXXXXX}

\section{Alunos: XXXXX, XXXXXX, XXXXX,}

\section{3응}

Bullying é uma situação caracterizada por atos agressivos verbais ou fisicos de maneira repetitiva por parte de um ou mais alunos contra um ou mais colegas. O termo inglês refere-se ao verbo "ameaçar, intimidar".

1 - Qual é a sua idade?

1) 12 a 15 .

2) 16 a 18 .

3) 19 a 22 .

4) Mais de 22.

2 - Qual o seu sexo?

1-( ) Masculino

$2-($ ) Feminino

3 - Você jä sofreu Bullying? Se sim, ande ocorreu? 1) Năo sofri

2) Em casa.

3) Na escola.

4) No trabalho.

5) Na rua.

4 - Quando coagido, que atitude tomou?

1) Nunca ful cosesido.

2) Procurel assistêncla de alguém.

3) Informel a parentes ou amigos.

4) Tentel dialogar com o Buller.

5) Me calel sobre essa situaç̆o.

5 - Dentro do seu grupo de amigos, alguém já safreu Bullying?

1-( ) 51 2-( ) Nลิ०

6 - Vocé já sofreu alguma violència, seja ela psicolägica ou fisica em sua casa?

$1-($ ) $\operatorname{sim}$

$$
\text { 2-( ) Nằ }
$$

7 - Conhece quantas pessoas que já sofreram Bulliying?

1) Nenhuma pessoa.

2) Até 3 pessoas.

3) De 4 a 5 pessoas.

4) De 6 a 8 pessoas.

5) Mals de 8 pessoas.

8 - Algum famillar seu fá alegou sofrer Bullying ou outra violência?

1-( ) sim 2-( ) Nà̀

9 - Vocé já sofreu abuso sexual?

1-( ) sim 2-( ) Nä̀

10 - sá presenciou o bullying em seu ambiente de trabalho?
$1-(1) \operatorname{sim}$
2-( ) Nằ

3-( ) Năo trabalho.
11 - Você adquiritu alguma fobla social por sofrer bulliying? $1-($ ) $51 \mathrm{~m}$ 2-( ) Naิ०

3-( )Nunca sofri bullying.

12 - Qual a sua apça sexual?

1-( ) Hétero 2-( ) Homossexual

13 - Já soffreu bullying devido a sua opçalo sexual? 1-( ) $51 \mathrm{~m} \quad 2-($ ) $N$ â०

14 - Tem algum amigo ou parente que já sofreu bullying devido a opçälo sexual?

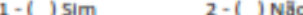

15 - Você considera o bullying um crime?

1-( ) sim 2-( ) Nă०

16 - Você acha que praticantes de bullying deveriam ser punidos pela lel? de que forma?

1) Prestaçåo de servicos comunitários.

2) Detidos.

3) Outros.

17 - Na sua escola ou ambiente de trabaho existem palestras sobre esse tipo de assunto?
1-( ) $51 \mathrm{~m}$
2-( ) NBo

18 - Já tamou medidas wolentas para com aqueles que praticaram alguma violência psicalógica ou fisica cam voce?

1) $\mathrm{Sim}$.

2) Nลิ๋

3) Sim, porém me arrependi.

4) Sou contra a violência.

5) N.D.A

19 - Você acha que pessoas praticantes de bullying precisam de assistência de um profissianal de saúde mental?

1-( ) $51 \mathrm{~m} \quad 2-($ ) Nåo

$20-$ E vacê, fá praticou bullying?

$1-()$ sim $2-(1)$ N30

Figura 3.1: Questionário sobre Bullying 
Podemos reparar que as perguntas foram criadas com responsabilidade e respeito ao tema, percebemos a preocupação em ressaltar que as perguntas foram formuladas de acordo com a problemática do tema buscando com elas enxergar solução para tal fato. Fica clara a posição do grupo em relação ao tema Bullying, o empenho e a participação de todos para sua elaboração.

As perguntas foram feitas utilizando respostas intervalar e respostas nominais, todas elas foram enumeradas para aplicação do princípio da contagem.

\subsection{A aplicação do Questionário.}

Este questionário foi aplicado no interior da Instituição de Ensino, sendo respondido por professores, técnicos, direção, colaboradores de manutenção e limpeza e na sua grande maioria pelos alunos dos turnos matutino e vespertino, perfazendo um total de quatrocentos e noventa e cinco formulários respondidos.

\subsection{Lançamento dos dados.}

Todos os grupos optaram por utilizar o lançamento eletrônico de dados, especificamente, fizeram os lançamentos na Planilha Eletrônica EXCEL da Microsoft. O professor interveio mostrando a melhor forma de lançamento dos dados na planilha, porém a grande maioria dos alunos já detinha algum conhecimento do trabalho com a planilha, bastou ao professor orientá-los quanto à utilização de algumas funções necessárias ao trabalho.

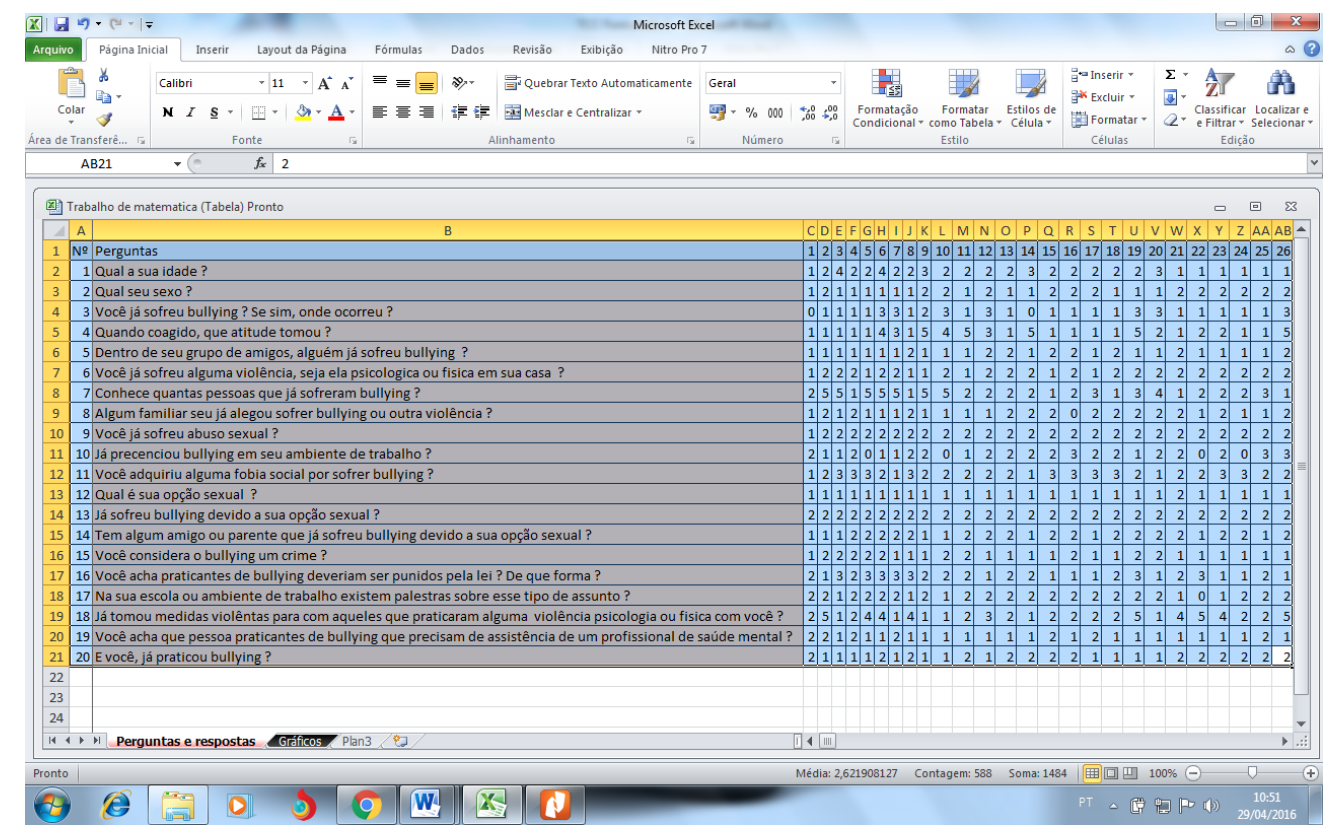

Figura 3.2: Lançamento na Planilha Excel 
Primeiramente foram relacionadas todas as perguntas contidas no questionário (Figura 3.2), notem que a primeira linha contém o número da pergunta, a descrição da pergunta e em seguida o sequencial do quantitativo de pessoas que responderam ao questionário. Abaixo deste sequencial são as respectivas respostas para cada pergunta.

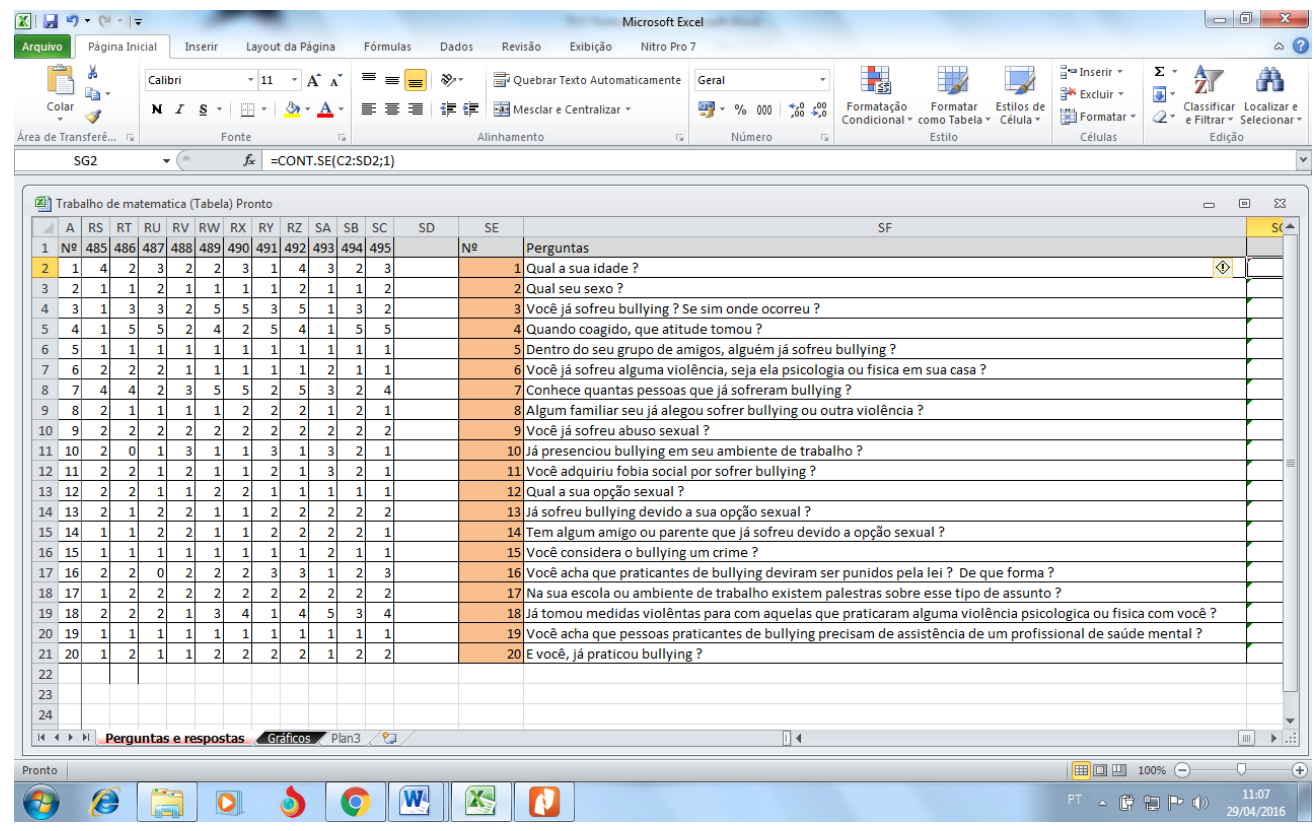

Figura 3.3: Final do lançamento do questionário

Reparem que são quatrocentos e noventa e cinco resposta para cada pergunta (Figura 3.3).

\subsection{Tabulação dos dados.}

Ainda no Excel, o professor orienta os grupos para a tabulação dos dados lançados. A forma mais simples e significativa é repetir as perguntas ao final dos lançamentos do questionário para utilizar futuramente na confecção dos gráficos (Figura 3.4).

No questionário as respostas foram numeradas até cinco, então, além das perguntas, teremos cinco colunas que serão utilizadas para agrupar as respostas dos questionários (Figura 3.4).

Para agrupar cada resposta, o professor deverá orientar os grupos para utilização da função do Excel "=CONT.SE()", ela calcula o número de células não vazias em um intervalo que corresponde a uma determinada condição. Na referida tabela, notemos que serão contados todas as células que estiverem no intervalo entre a coluna C2 e SD2 que contenham o número 1, nesse caso foram encontrados duzentos e nove resul- 


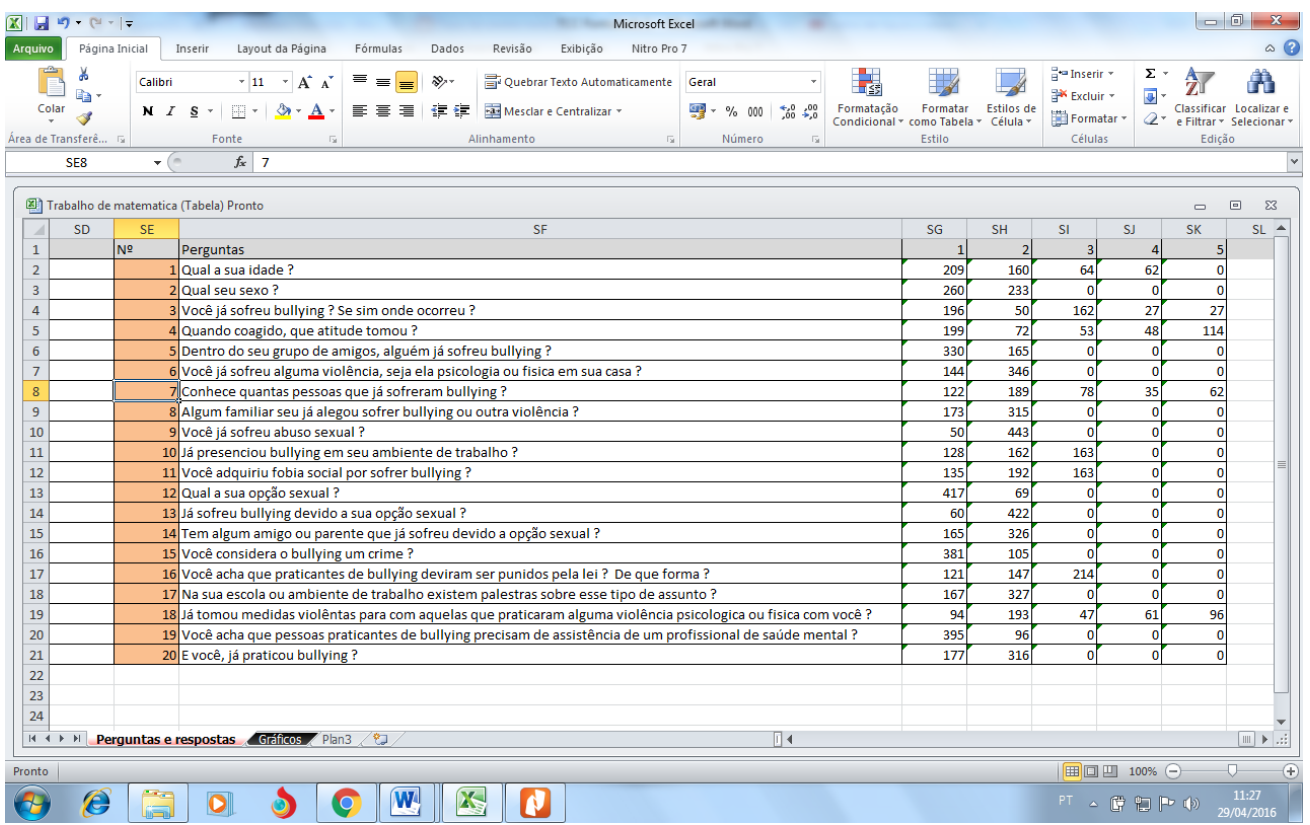

Figura 3.4: Preparação para tabulação dos dados lançados

tados com a resposta 1, a função é escrita da seguinte forma: "=CONT.SE(C2:SD2;1)" (Figura 3.5).

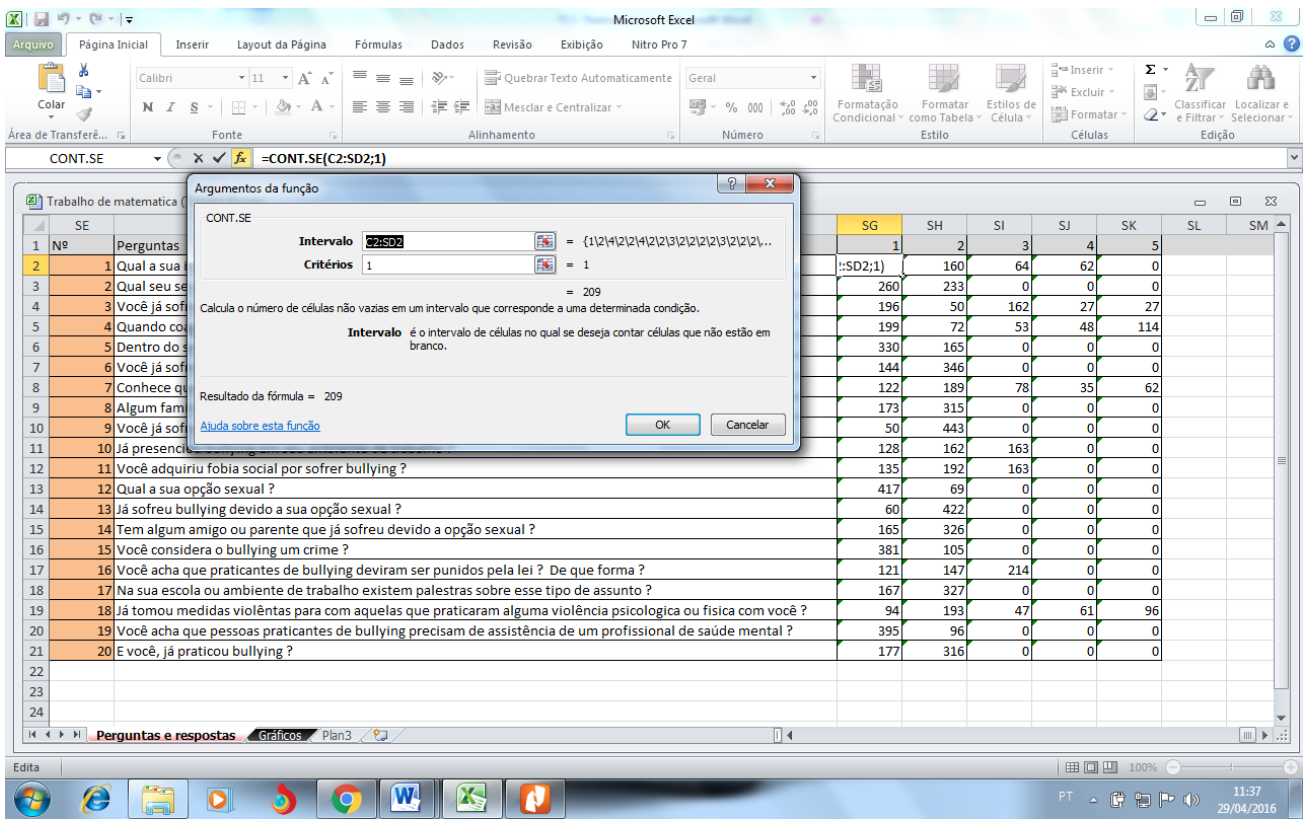

Figura 3.5: Utilizando a função =CONT.SE()

Será repetida a função para as outras respostas, respeitando em cada caso o critério eleito.

Com os resultados tabulados passaremos para a elaboração dos gráficos. 


\subsection{Gráficos de cada pergunta.}

\begin{tabular}{|l|l|l|l|l|l|l|}
\hline & & 12 a 15 & 16 a 18 & 19 a 22 & $\begin{array}{l}\text { Mais de } \\
22\end{array}$ & $\begin{array}{l}\text { Brancos ou } \\
\text { nulos }\end{array}$ \\
\hline 1 & $\begin{array}{l}\text { Qual a sua } \\
\text { idade? }\end{array}$ & 209 & 160 & 64 & 62 & 0 \\
\hline
\end{tabular}

Tabela 3.1: Qual a sua idade?
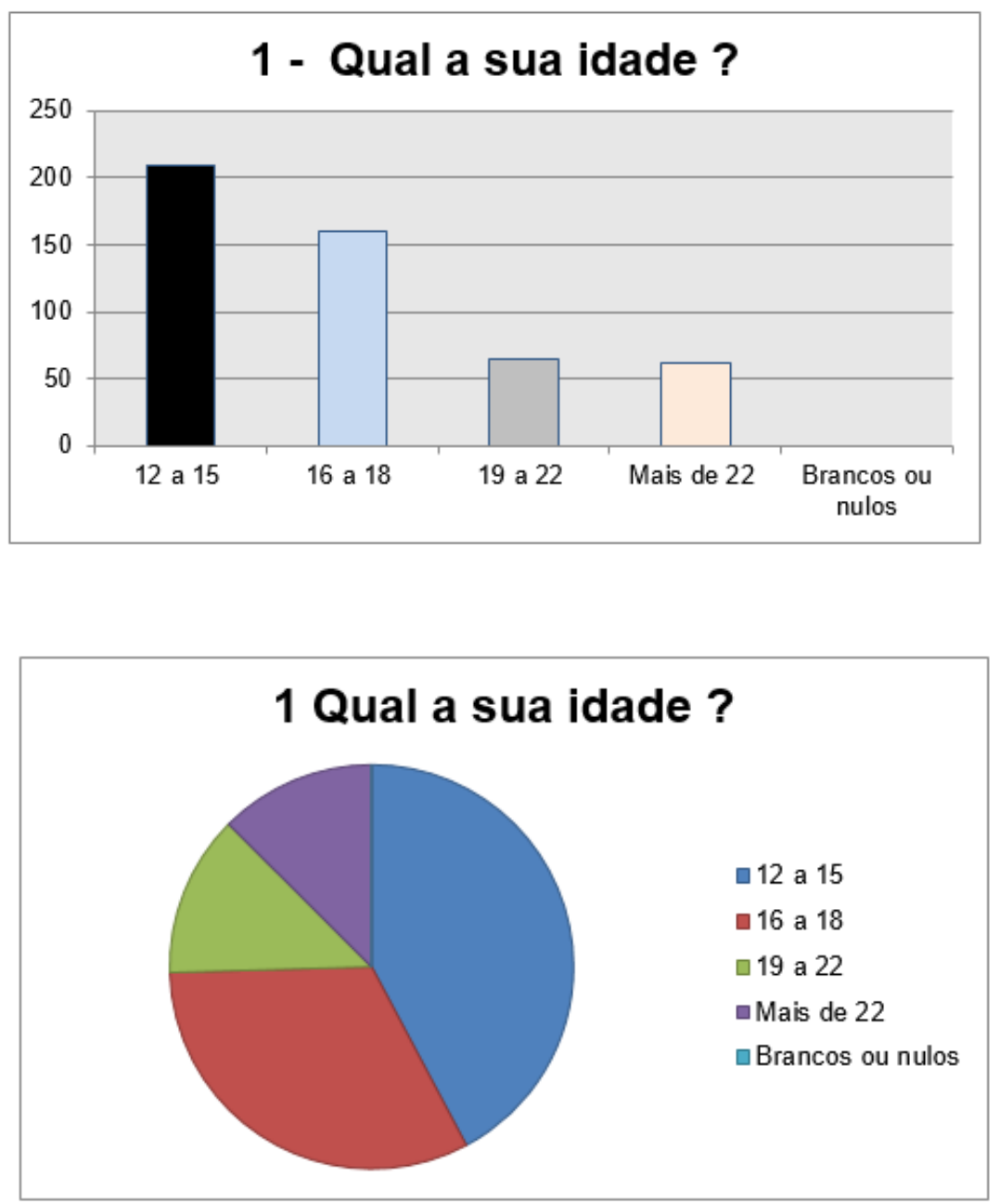

Figura 3.6: Qual a sua idade? 


\begin{tabular}{|l|l|l|l|l|}
\hline & & Masculino & Feminino & $\begin{array}{l}\text { Brancos ou } \\
\text { nulos }\end{array}$ \\
\hline 2 & $\begin{array}{l}\text { Qual seu } \\
\text { sexo? }\end{array}$ & 260 & 233 & 2 \\
\hline
\end{tabular}

Tabela 3.2: Qual o seu sexo?
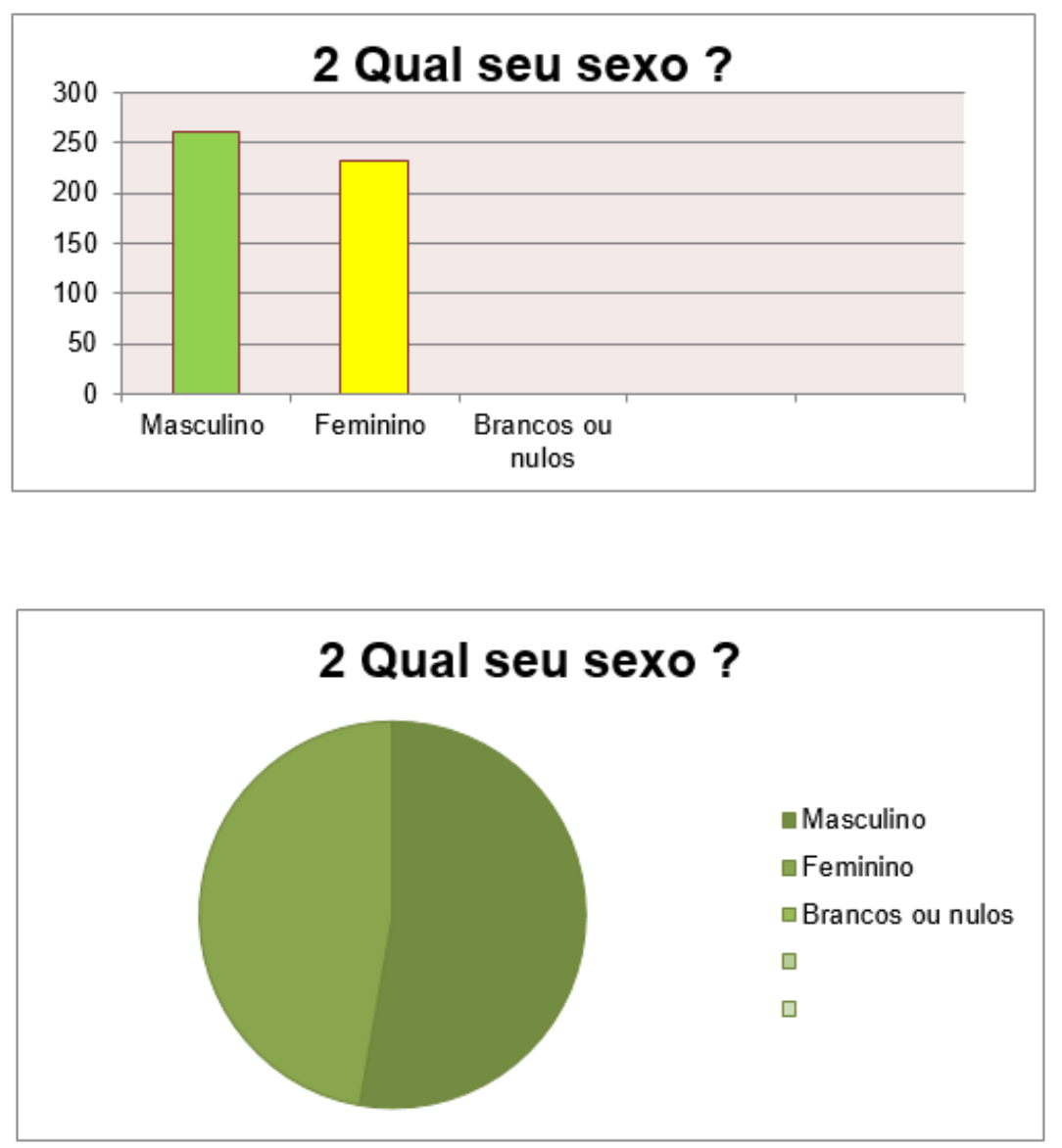

Figura 3.7: Qual o seu sexo? 


\begin{tabular}{|l|l|l|l|l|l|l|}
\hline & & $\begin{array}{l}\text { Não } \\
\text { sofri }\end{array}$ & $\begin{array}{l}\text { Em } \\
\text { casa }\end{array}$ & $\begin{array}{l}\text { Na es- } \\
\text { cola }\end{array}$ & $\begin{array}{l}\text { No tra- } \\
\text { balho }\end{array}$ & Na rua \\
\hline 3 & $\begin{array}{l}\text { Você já sofreu } \\
\text { bullying ? Se } \\
\text { sim, onde ocor- } \\
\text { reu? }\end{array}$ & 196 & 50 & 162 & 27 & 27 \\
\hline
\end{tabular}

Tabela 3.3: Você já sofreu bullying? Se sim onde ocorreu?

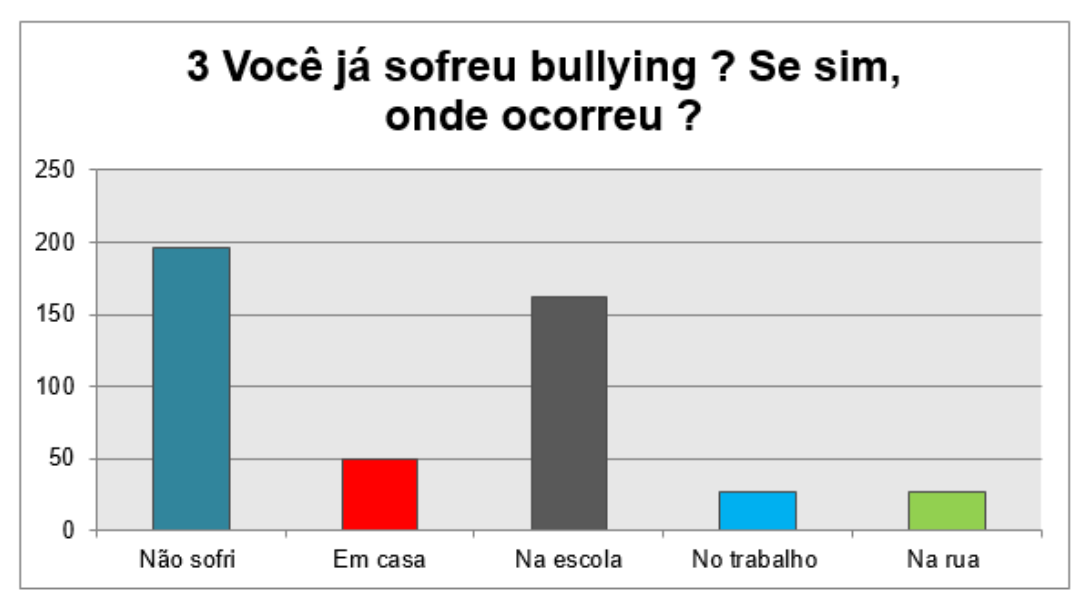

Figura 3.8: Você já sofreu bullying? Se sim onde ocorreu?

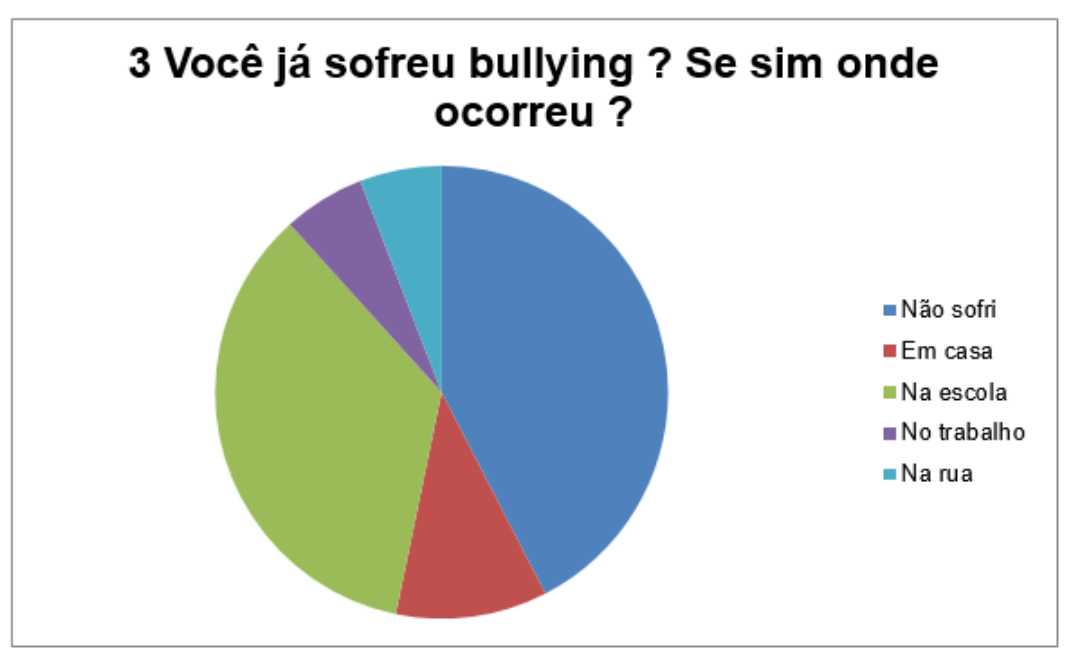




\begin{tabular}{|l|l|l|l|l|l|l|}
\hline & $\begin{array}{l}\text { Nunca } \\
\text { fui co- } \\
\text { agido } \\
\text { as- } \\
\text { sistência } \\
\text { de } \\
\text { alguém }\end{array}$ & $\begin{array}{l}\text { Informei a } \\
\text { parentes ou } \\
\text { amigos }\end{array}$ & $\begin{array}{l}\text { Tentei } \\
\text { dialogar } \\
\text { com o } \\
\text { Buller }\end{array}$ & $\begin{array}{l}\text { Me calei } \\
\text { sobre essa } \\
\text { situação }\end{array}$ \\
\hline 4 & $\begin{array}{l}\text { Quando } \\
\text { coagido, } \\
\text { que atitude } \\
\text { tomou? }\end{array}$ & 199 & 72 & 53 & 48 & 114 \\
\hline
\end{tabular}

Tabela 3.4: Quando coagido, que atitude tomou ?
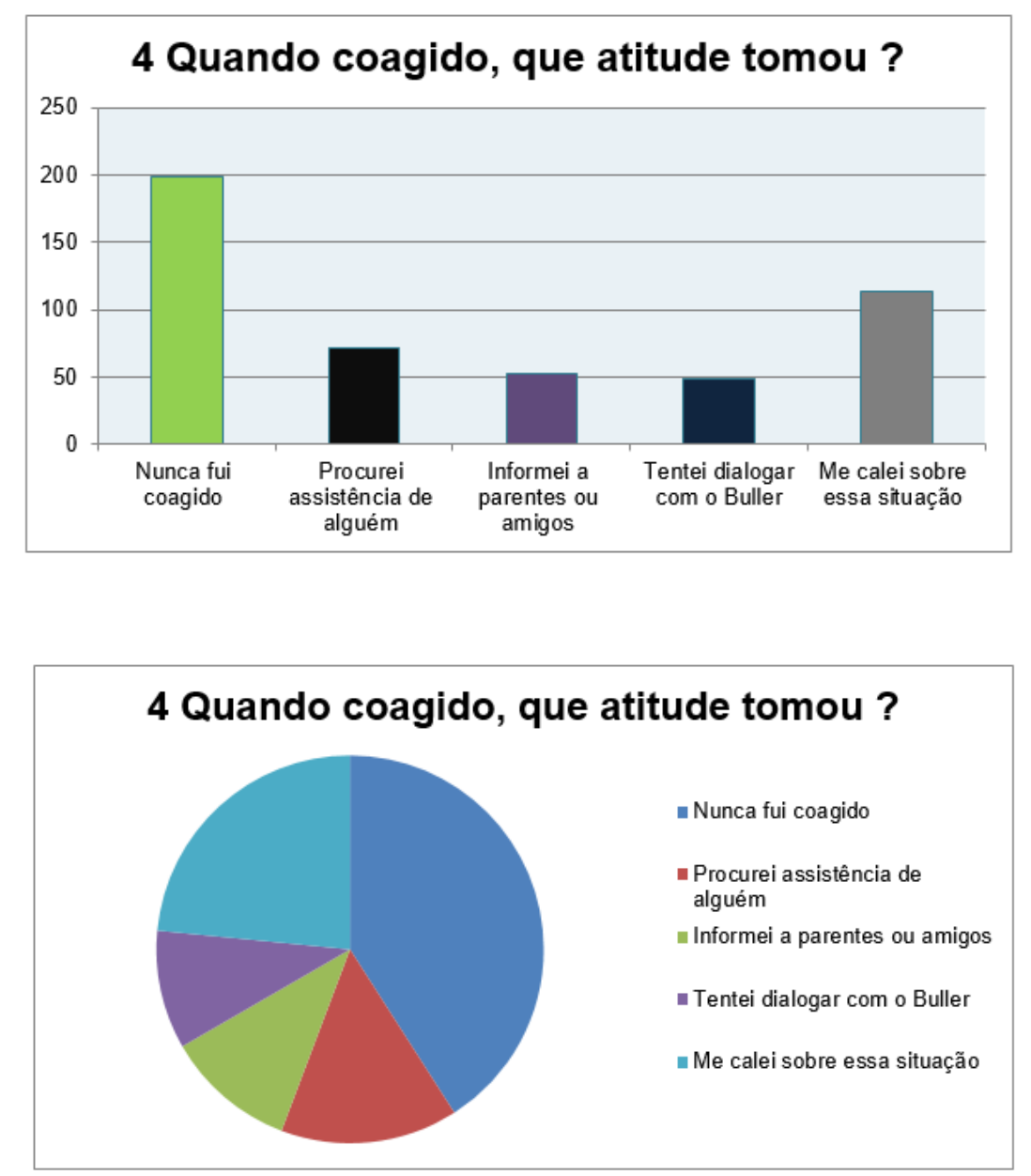

Figura 3.9: Quando coagido, que atitude tomou? 


\begin{tabular}{|l|l|l|l|l|}
\hline 5 & Sim & Não & $\begin{array}{l}\text { Brancos ou } \\
\text { nulos }\end{array}$ \\
\hline $\begin{array}{l}\text { Dentro do seu grupo de } \\
\text { amigos, alguém já sofreu } \\
\text { bullying? }\end{array}$ & 330 & 165 & 0 \\
\hline
\end{tabular}

Tabela 3.5: Dentro do seu grupo de amigos, alguém já sofreu bullying ?
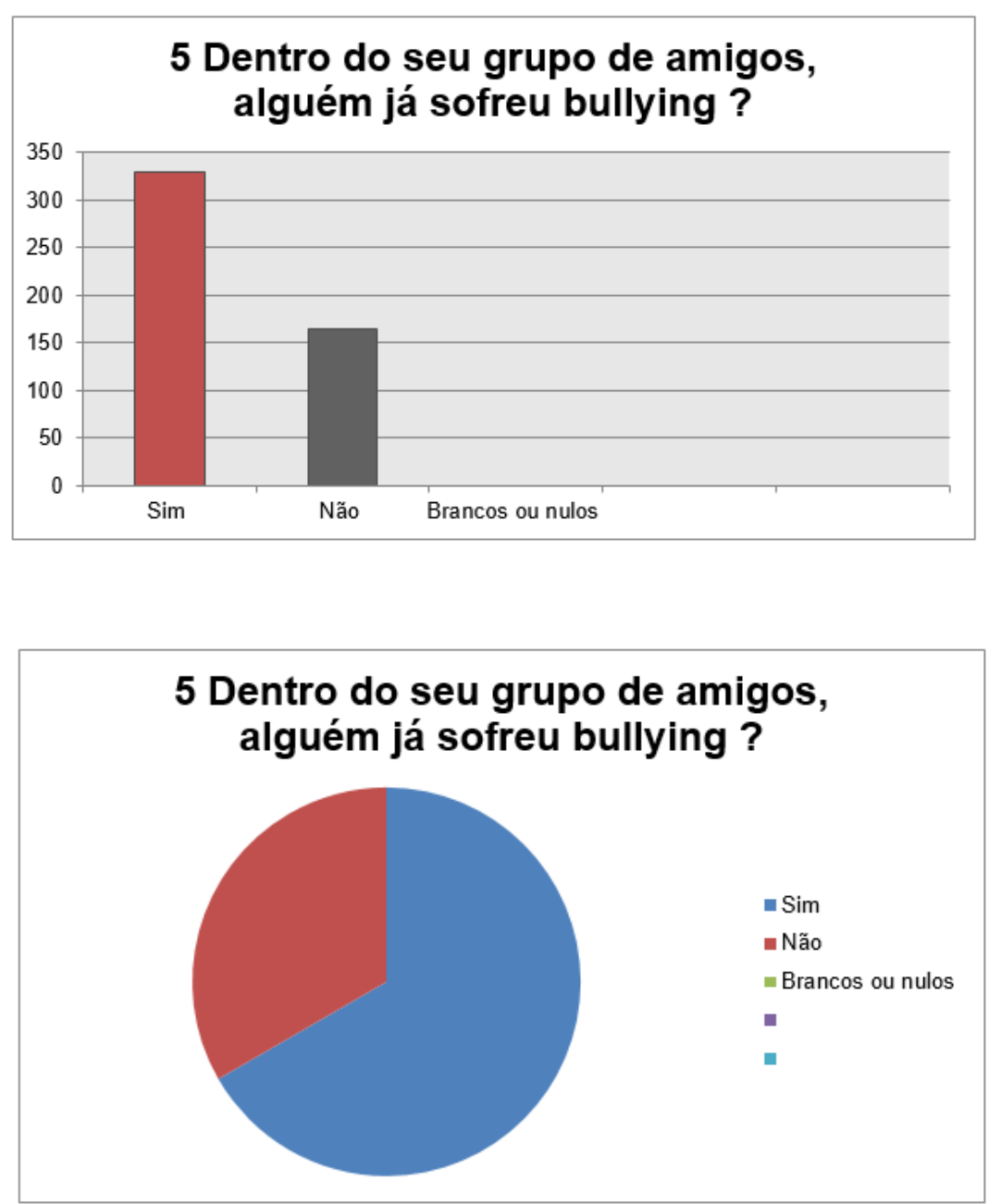

Figura 3.10: Dentro do seu grupo de amigos, alguém já sofreu bullying ? 


\begin{tabular}{|l|l|l|l|l|}
\hline 6 & $\begin{array}{l}\text { Você já sofreu alguma } \\
\text { violência, seja ela psicologia } \\
\text { ou física em sua casa? }\end{array}$ & 144 & 346 & 0 \\
\hline
\end{tabular}

Tabela 3.6: Você já sofreu alguma violência, seja ela psicológica ou física em sua casa?
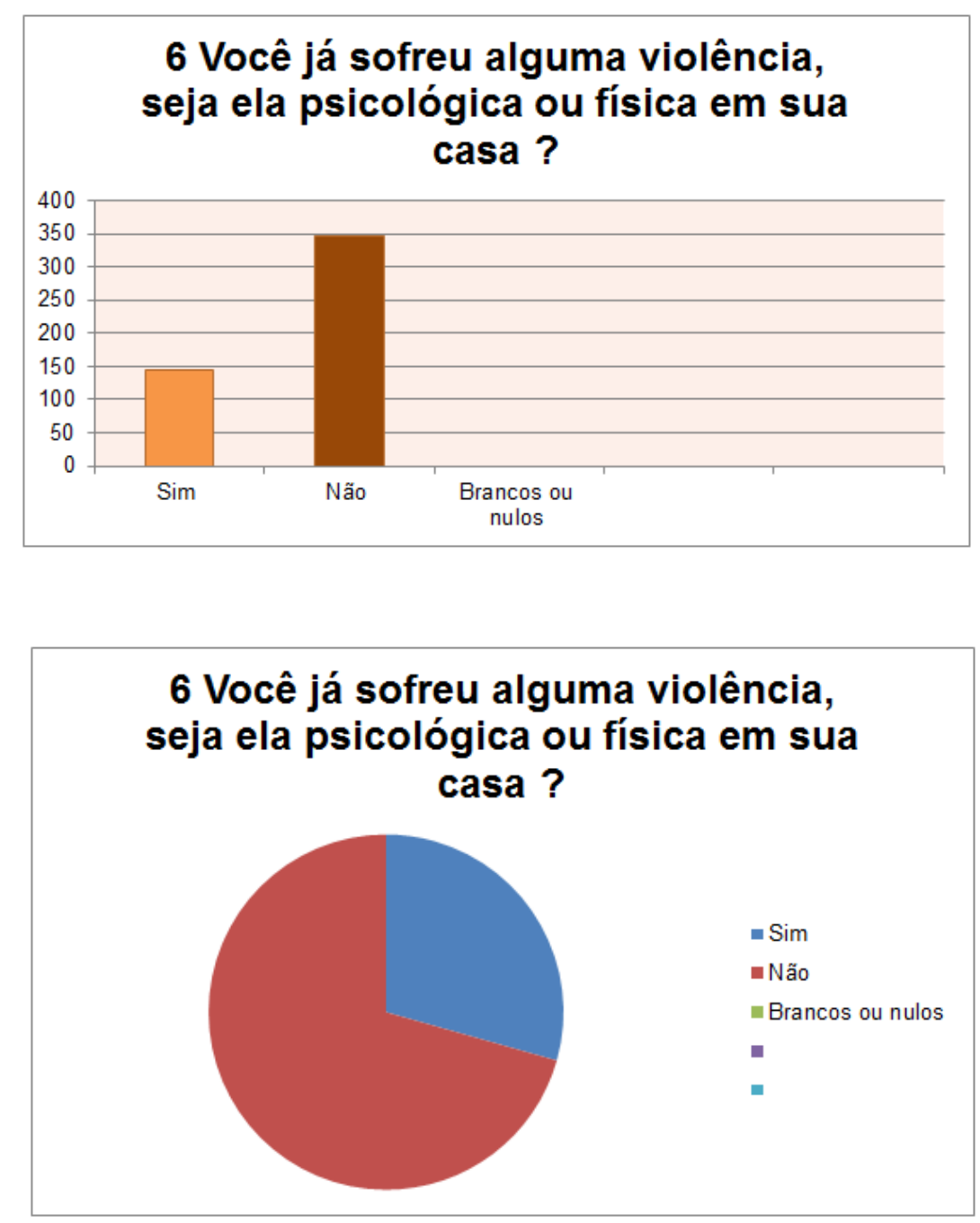

Figura 3.11: Você já sofreu alguma violência, seja ela psicológica ou física em sua casa? 


\begin{tabular}{|l|l|l|l|l|l|l|}
\hline & & $\begin{array}{l}\text { NenhumaAté } \\
\text { pessoa }\end{array}$ & $\begin{array}{l}\text { De 4 a } \\
\text { pes- } \\
\text { soas }\end{array}$ & $\begin{array}{l}\text { De 6 a } \\
5 \text { pes- } \\
\text { soas }\end{array}$ & $\begin{array}{l}\text { Mais de 8 } \\
\text { soas }\end{array}$ & pessoas \\
\hline 7 & $\begin{array}{l}\text { Conhece } \\
\text { quantas pes- } \\
\text { soas que } \\
\text { já sofreram } \\
\text { bullying ? }\end{array}$ & 122 & 189 & 78 & 35 & 62 \\
\hline
\end{tabular}

Tabela 3.7: Conhece quantas pessoas que já sofreram bullying?
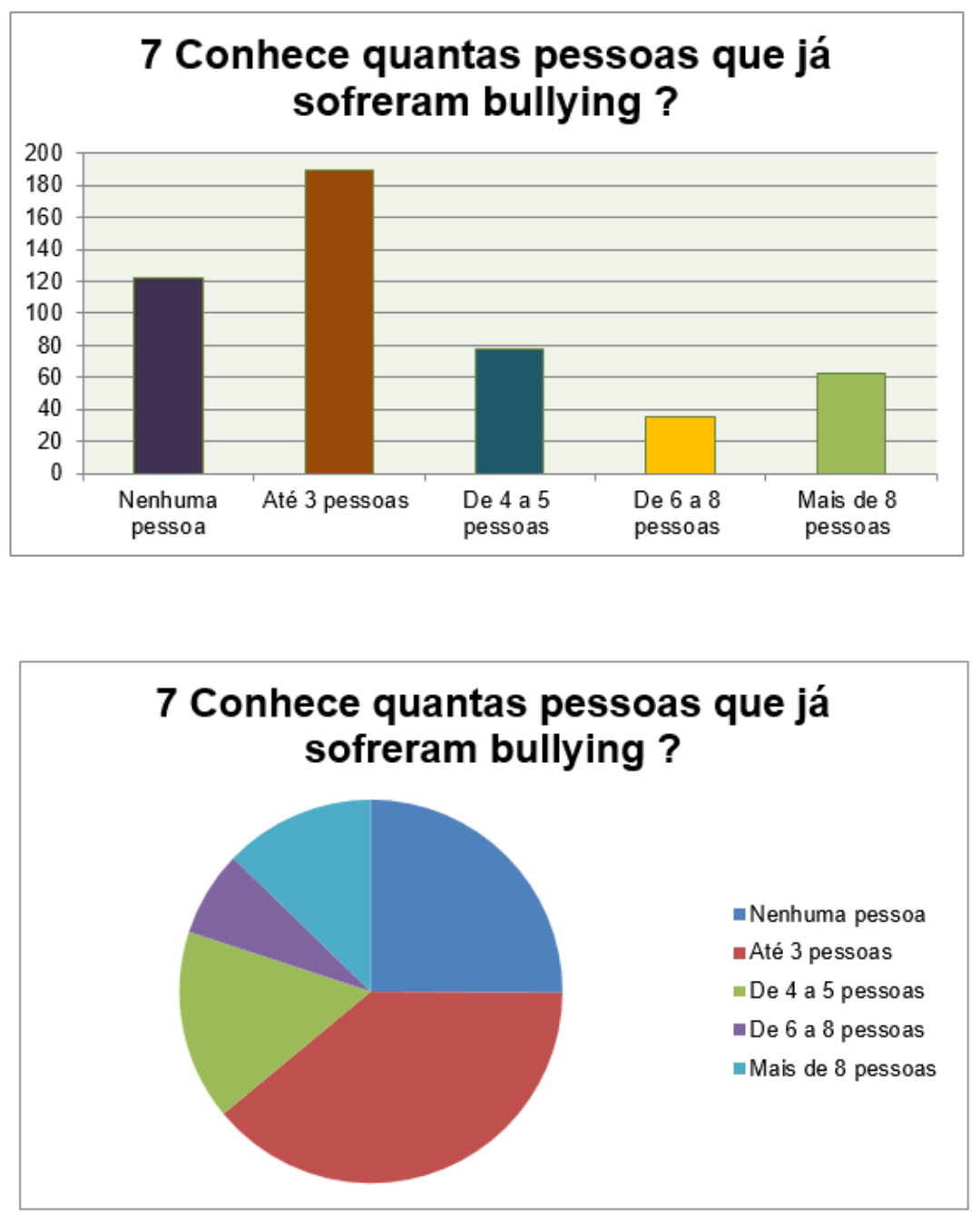

Figura 3.12: Conhece quantas pessoas que já sofreram bullying? 


\begin{tabular}{|l|l|l|l|l|}
\hline 8 & $\begin{array}{l}\text { Sim } \\
\text { Algum familiar seu já ale- } \\
\text { gou sofrer bullying ou ou- } \\
\text { tra violência? }\end{array}$ & 173 & 315 & $\begin{array}{l}\text { Brancos ou } \\
\text { nulos }\end{array}$ \\
\hline
\end{tabular}

Tabela 3.8: Algum familiar seu já alegou sofrer bullying ou outra violência ?
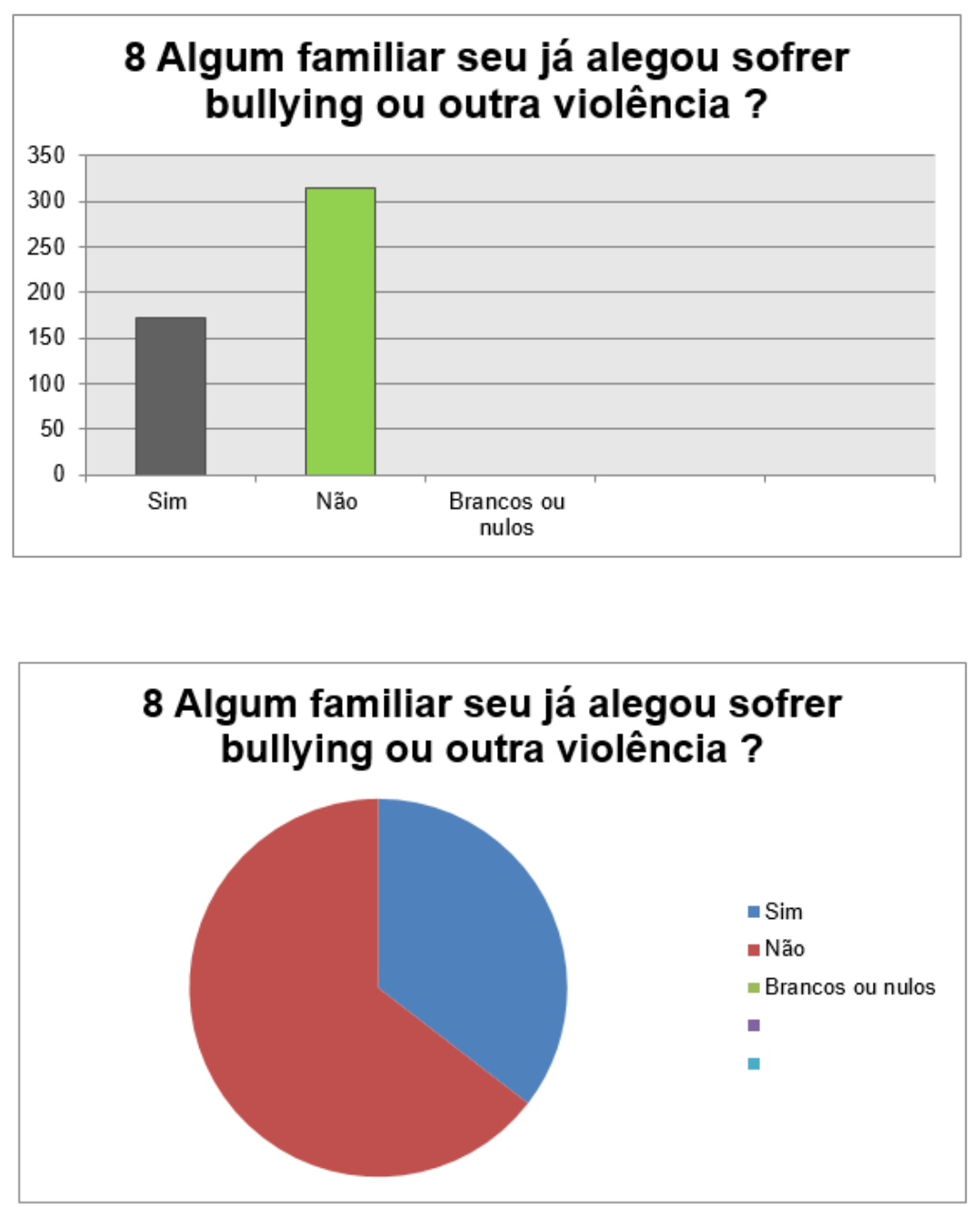

Figura 3.13: Algum familiar seu já alegou sofrer bullying ou outra violência ? 


\begin{tabular}{|l|l|l|l|l|}
\hline & & Sim & Não & Brancos ou nulos \\
\hline 9 & $\begin{array}{l}\text { Você já sofreu abuso } \\
\text { sexual ? }\end{array}$ & 50 & 443 & 0 \\
\hline
\end{tabular}

Tabela 3.9: Você já sofreu abuso sexual ?
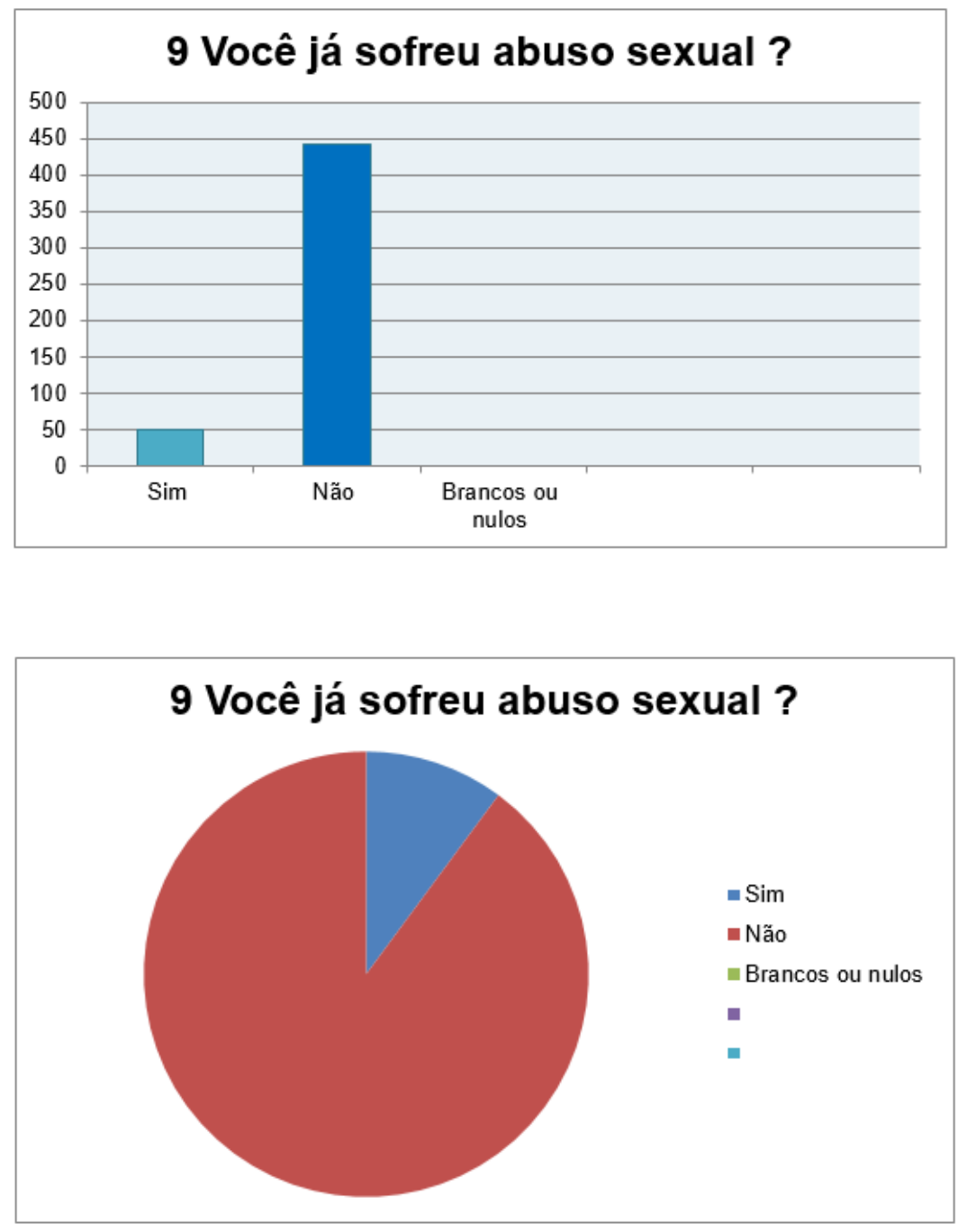

Figura 3.14: Você já sofreu abuso sexual ? 


\begin{tabular}{|l|l|l|l|l|l|}
\hline & & Sim & Não & $\begin{array}{l}\text { Não traba- } \\
\text { lho }\end{array}$ & $\begin{array}{l}\text { Brancos ou } \\
\text { nulos }\end{array}$ \\
\hline 10 & $\begin{array}{l}\text { Já presenciou } \\
\text { bullying em seu } \\
\text { ambiente de trabalho } \\
?\end{array}$ & 128 & 162 & 163 & 0 \\
\hline
\end{tabular}

Tabela 3.10: Já presenciou bullying em seu ambiente de trabalho ?
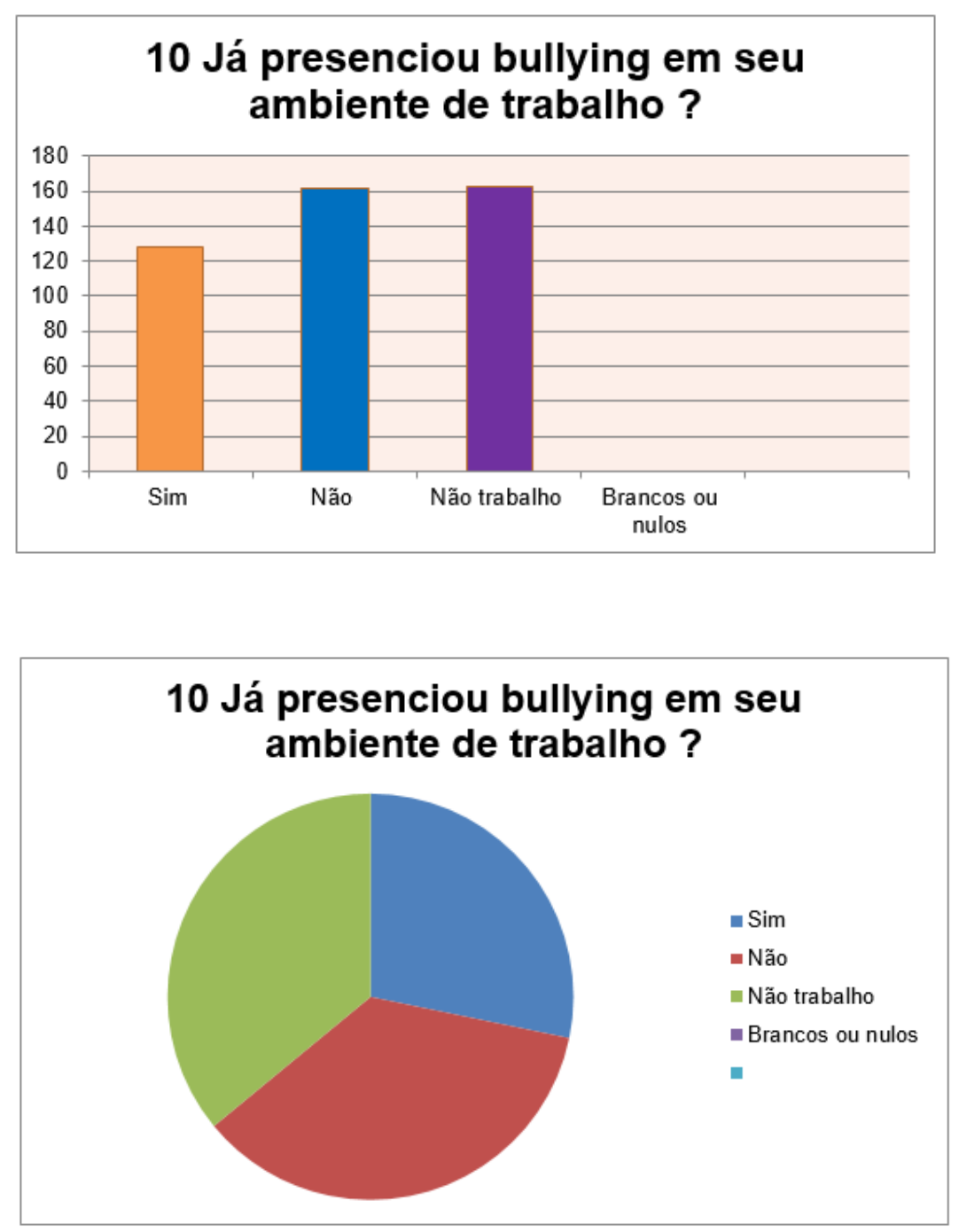

Figura 3.15: Já presenciou bullying em seu ambiente de trabalho ? 


\begin{tabular}{|c|l|l|l|l|l|}
\hline & & Sim & Não & $\begin{array}{l}\text { Nunca } \\
\text { sofri } \\
\text { bullying }\end{array}$ & $\begin{array}{l}\text { Brancos ou } \\
\text { nulos }\end{array}$ \\
\hline 11 & $\begin{array}{l}\text { Você adquiriu fo- } \\
\text { bia social por so- } \\
\text { frer bullying? }\end{array}$ & 135 & 192 & 163 & 0 \\
\hline
\end{tabular}

Tabela 3.11: Você adquiriu fobia social por sofrer bullying?
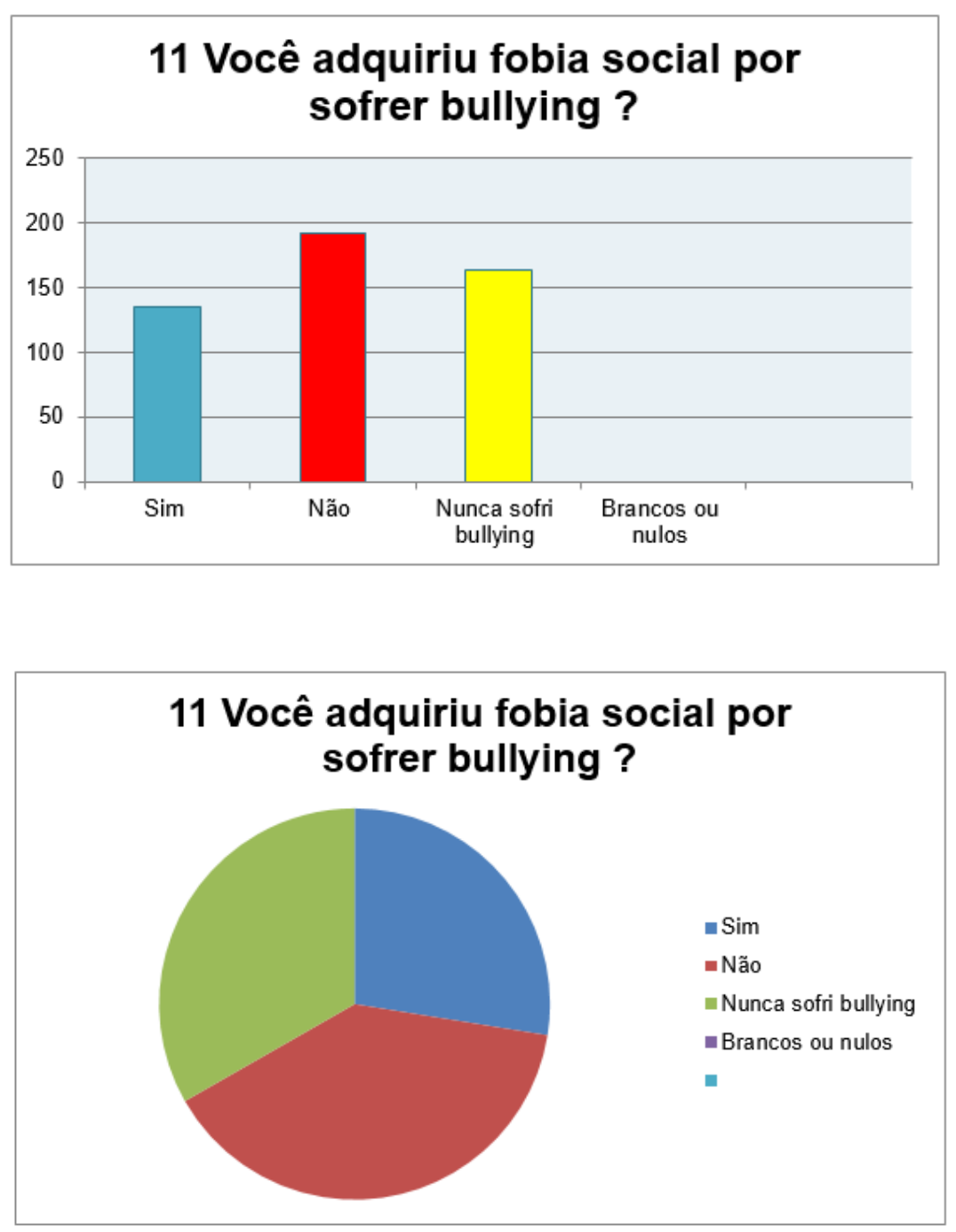

Figura 3.16: Você adquiriu fobia social por sofrer bullying ? 


\begin{tabular}{|l|l|l|l|l|}
\hline 12 & Hétero & HomossexuaBrancos ou nulos \\
\hline $\begin{array}{l}\text { Qual a sua opção } \\
\text { sexual ? }\end{array}$ & 417 & 69 & 0 \\
\hline
\end{tabular}

Tabela 3.12: Qual a sua opção sexual ?
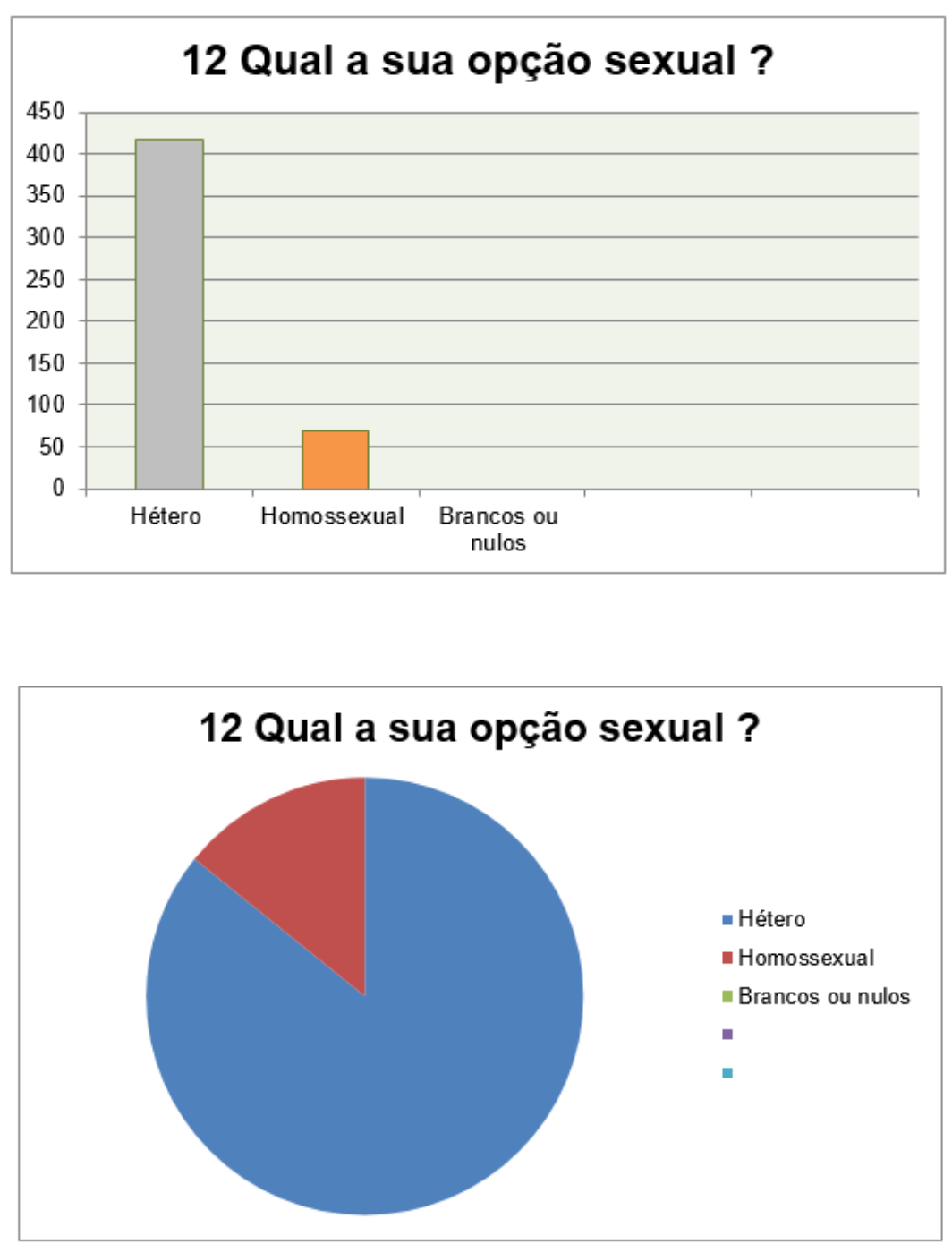

Figura 3.17: Qual a sua opção sexual ? 


\begin{tabular}{|l|l|l|l|l|}
\hline 13 & Sim & Não & Brancos ou nulos \\
\hline $\begin{array}{l}\text { Já sofreu bullying } \\
\text { devido a sua opção } \\
\text { sexual ? }\end{array}$ & 60 & 422 & 0 \\
\hline
\end{tabular}

Tabela 3.13: Já sofreu bullying devido a sua opção sexual ?
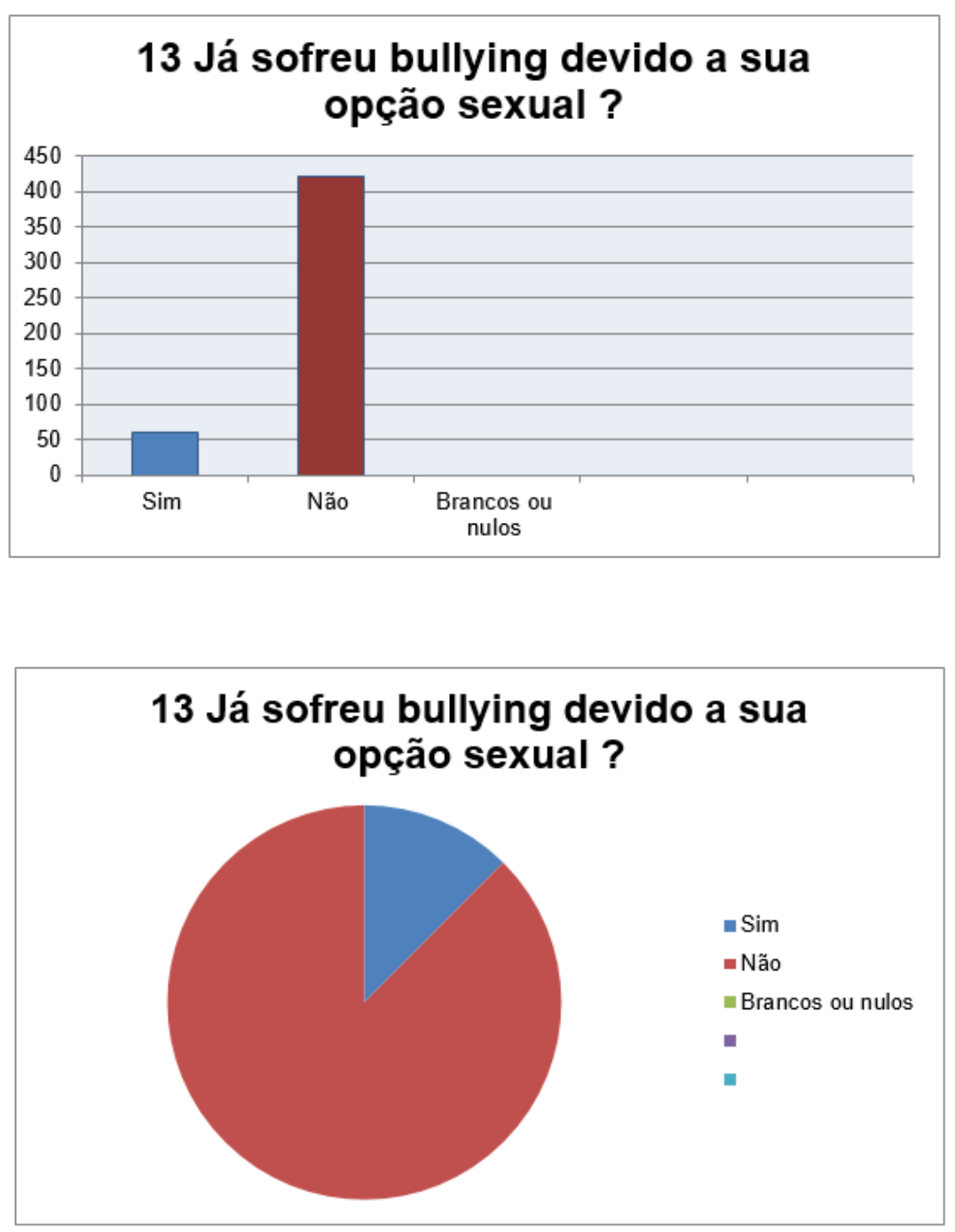

Figura 3.18: Já sofreu bullying devido a sua opção sexual ? 


\begin{tabular}{|l|l|l|l|l|}
\hline 14 & Sim & Não & Brancos ou nulos \\
\hline $\begin{array}{l}\text { Tem algum amigo ou } \\
\text { parente que já sofreu } \\
\text { devido a opção se- } \\
\text { xual ? }\end{array}$ & 165 & 326 & 0 \\
\hline
\end{tabular}

Tabela 3.14: Tem algum amigo ou parente que já sofreu devido a opção sexual ?
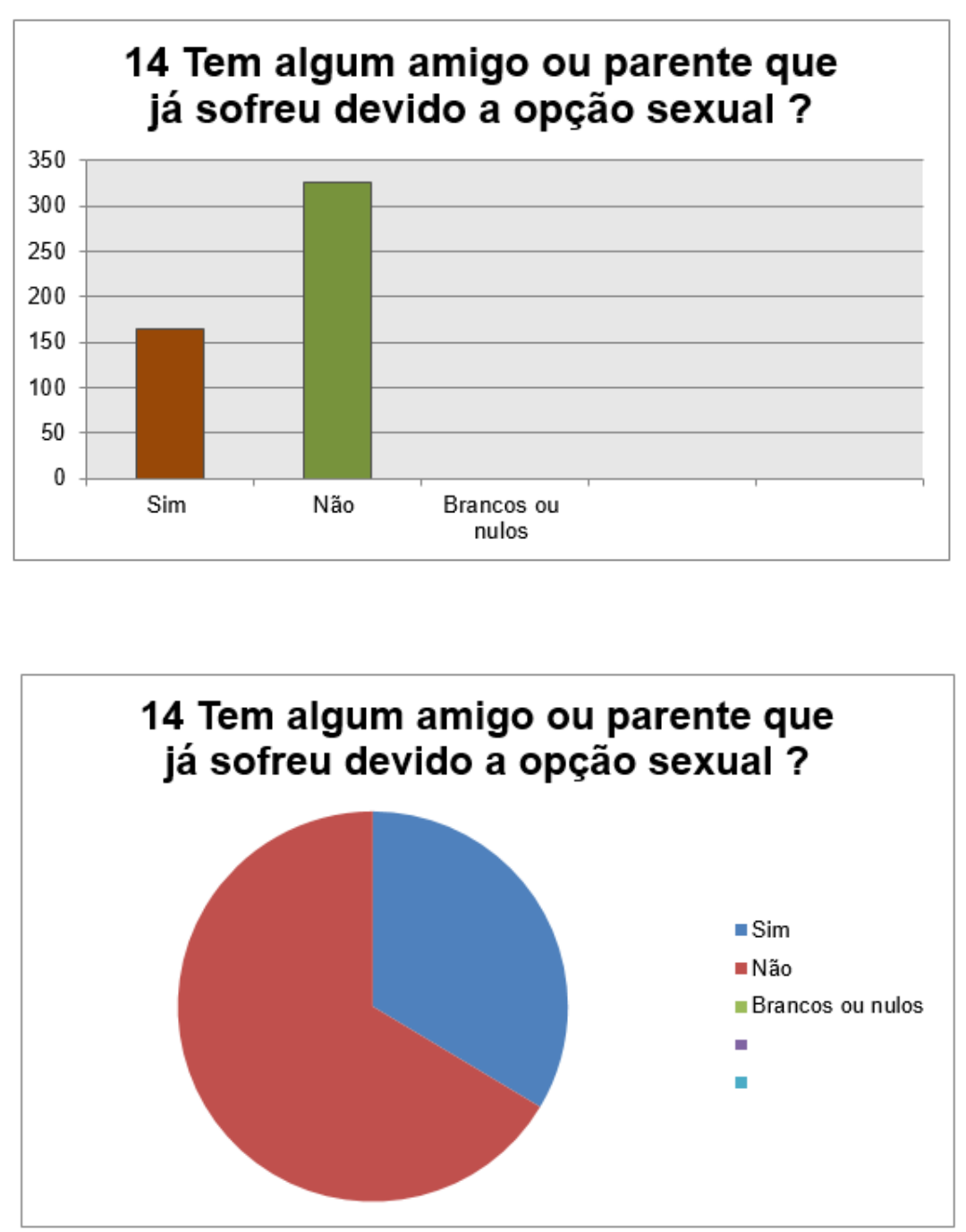

Figura 3.19: Tem algum amigo ou parente que já sofreu devido a opção sexual ? 


\begin{tabular}{|l|l|l|l|l|}
\hline 15 & $\begin{array}{l}\text { Vim } \\
\text { Você considera o } \\
\text { bullying um crime } \\
?\end{array}$ & 381 & 105 & 0 \\
\hline
\end{tabular}

Tabela 3.15: Você considera o bullying um crime ?
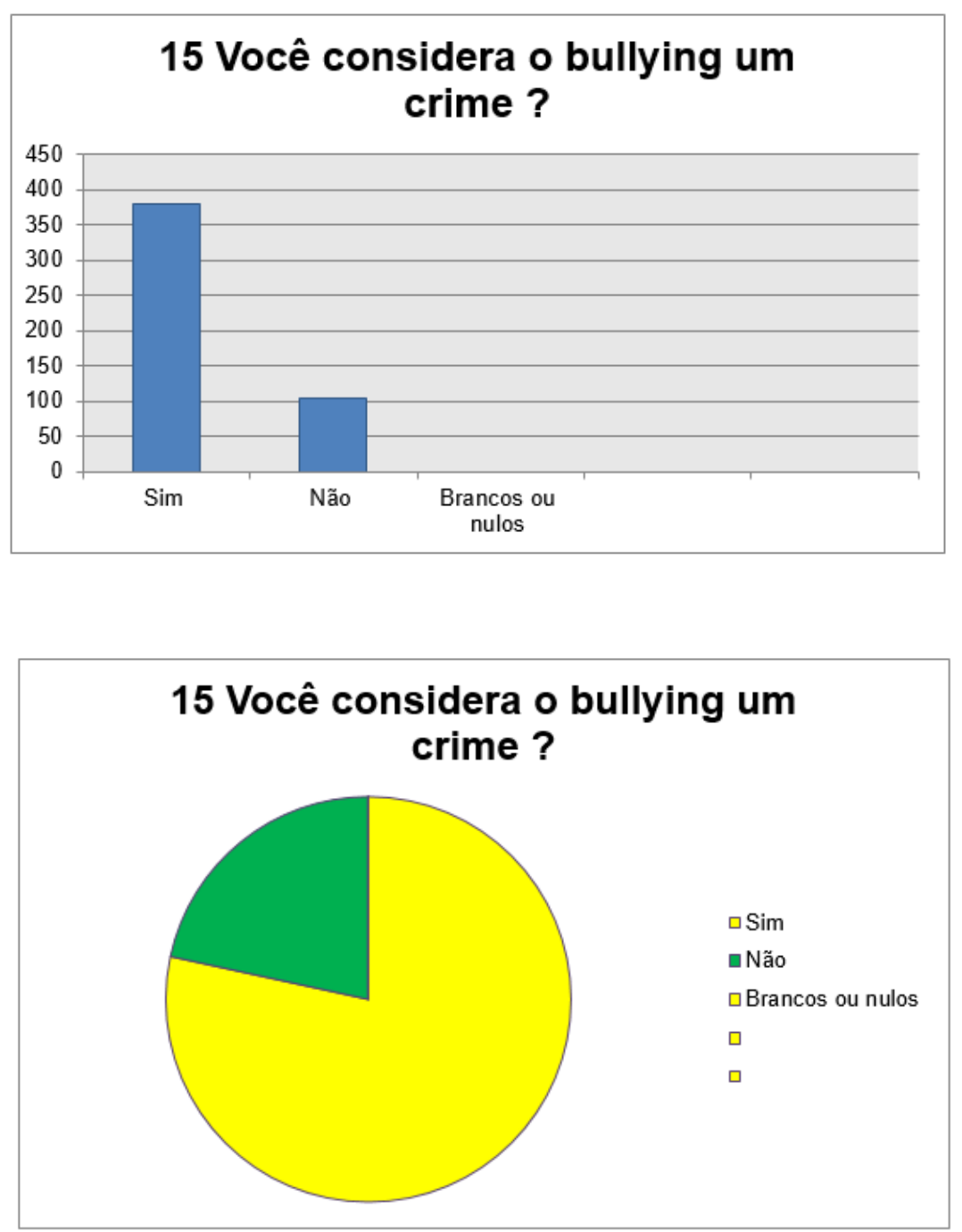

Figura 3.20: Você considera o bullying um crime? 


\begin{tabular}{|l|l|l|l|l|l|}
\hline & & $\begin{array}{l}\text { Prestação de } \\
\text { seviços co- } \\
\text { munitários }\end{array}$ & Detidos & Outros & $\begin{array}{l}\text { Brancos } \\
\text { ou nu- } \\
\text { los }\end{array}$ \\
\hline 16 & $\begin{array}{l}\text { Você acha que pra- } \\
\text { ticantes de bullying } \\
\text { deviram ser punidos } \\
\text { pela lei ? De que } \\
\text { forma? }\end{array}$ & 121 & 147 & 214 & 0 \\
\hline
\end{tabular}

Tabela 3.16: Você acha que praticantes de bullying deviram ser punidos pela lei ? De que forma?
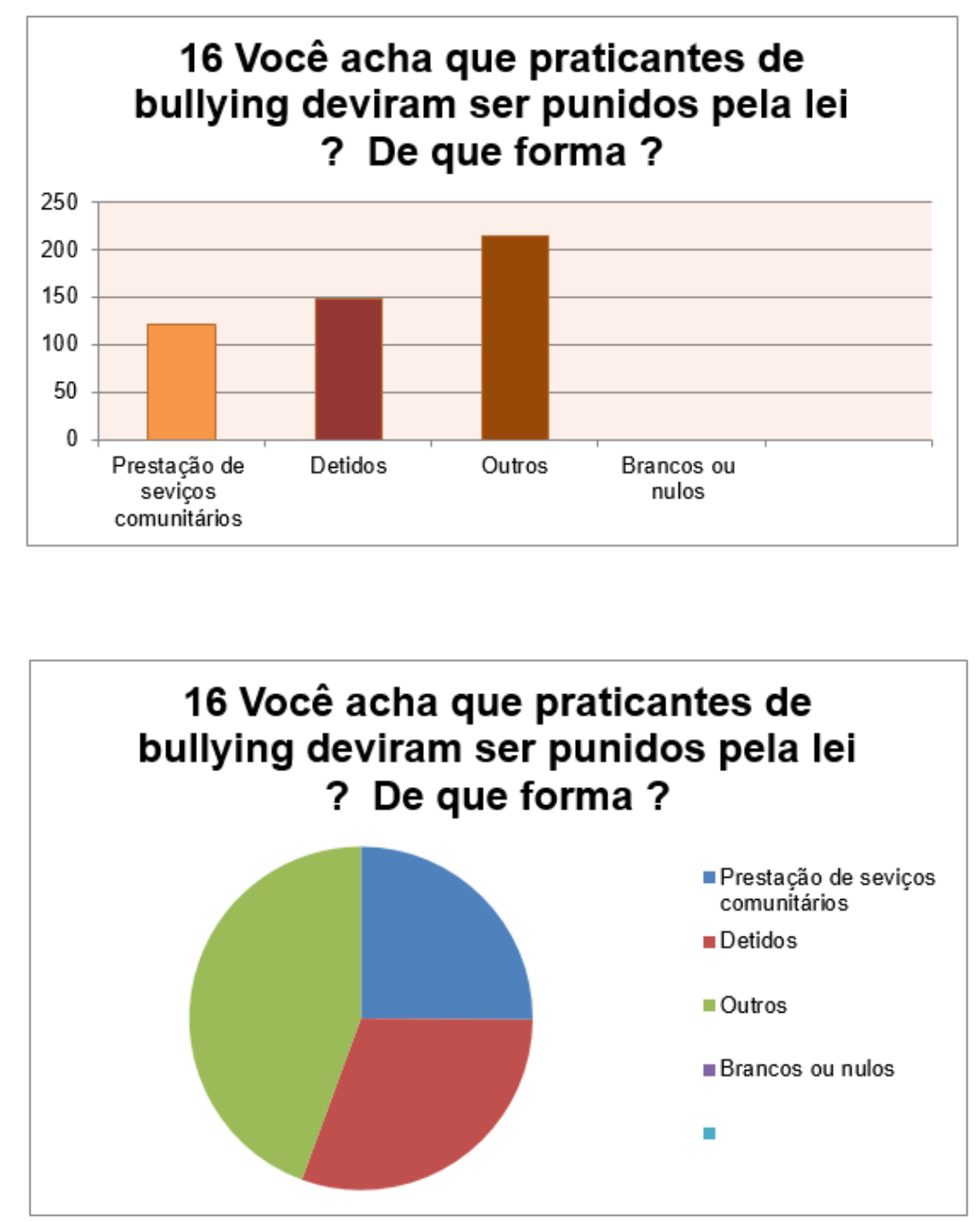

Figura 3.21: Você acha que praticantes de bullying deviram ser punidos pela lei ? De que forma? 


\begin{tabular}{|l|l|l|l|l|}
\hline & & Sim & Não & Brancos ou nulos \\
\hline 17 & $\begin{array}{l}\text { Na sua escola ou am- } \\
\text { biente de trabalho } \\
\text { existem palestras so- } \\
\text { bre esse tipo de as- } \\
\text { sunto? }\end{array}$ & 327 & 0 \\
\hline
\end{tabular}

Tabela 3.17: Na sua escola ou ambiente de trabalho existem palestras sobre esse tipo de assunto?
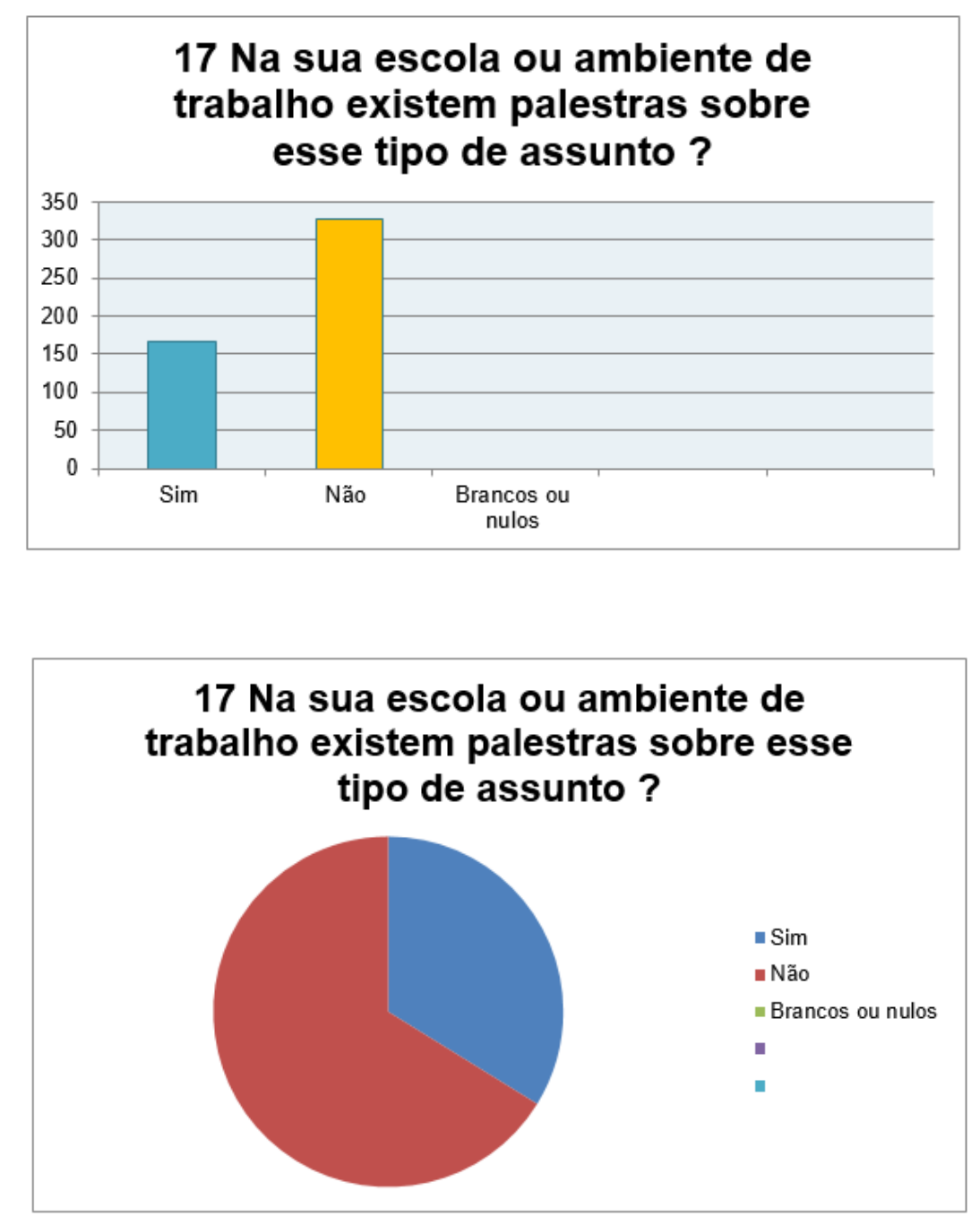

Figura 3.22: Na sua escola ou ambiente de trabalho existem palestras sobre esse tipo de assunto ? 


\begin{tabular}{|l|l|l|l|l|l|l|}
\hline & & Sim & Não & $\begin{array}{l}\text { Sim, porém } \\
\text { me arre- } \\
\text { pendi }\end{array}$ & $\begin{array}{l}\text { Sou } \\
\text { contra } \\
\text { violência }\end{array}$ & N.D.A \\
\hline 18 & $\begin{array}{l}\text { Já tomou } \\
\text { medidas violen- } \\
\text { tas para com } \\
\text { aquelas que } \\
\text { praticaram al- } \\
\text { guma violência } \\
\text { psicológica ou } \\
\text { física com você } \\
?\end{array}$ & 193 & 47 & 61 & 96 \\
\hline
\end{tabular}

Tabela 3.18: Já tomou medidas violentas para com aquelas que praticaram alguma violência psicológica ou física com você ?
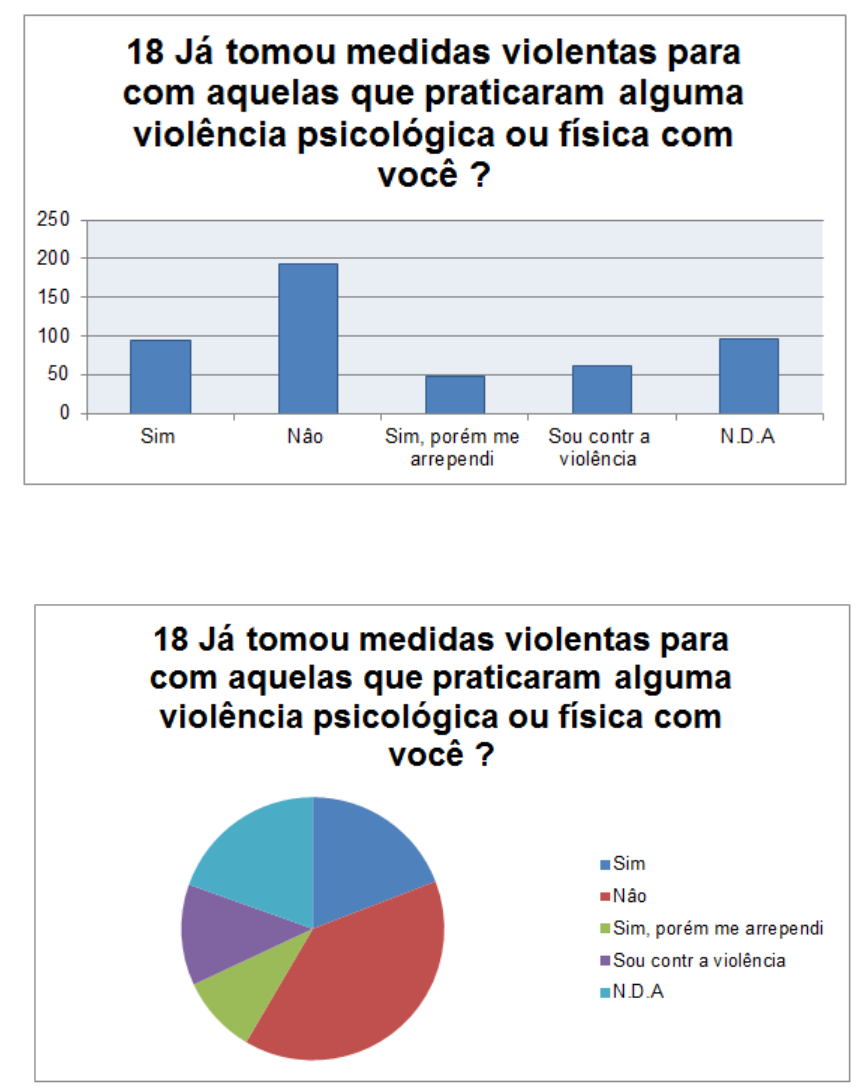

Figura 3.23: Já tomou medidas violentas para com aquelas que praticaram alguma violência psicológica ou física com você ? 


\begin{tabular}{|c|c|c|c|c|}
\hline & & Sim & Não & Brancos ou nulos \\
\hline 19 & $\begin{array}{l}\text { Você acha que } \\
\text { pessoas pratican- } \\
\text { tes de bullying } \\
\text { precisam de as- } \\
\text { sistência de um } \\
\text { profissional de } \\
\text { saúde mental? }\end{array}$ & 395 & 96 & 0 \\
\hline
\end{tabular}

Tabela 3.19: Você acha que pessoas praticantes de bullying precisam de assistência de um profissional de saúde mental ?
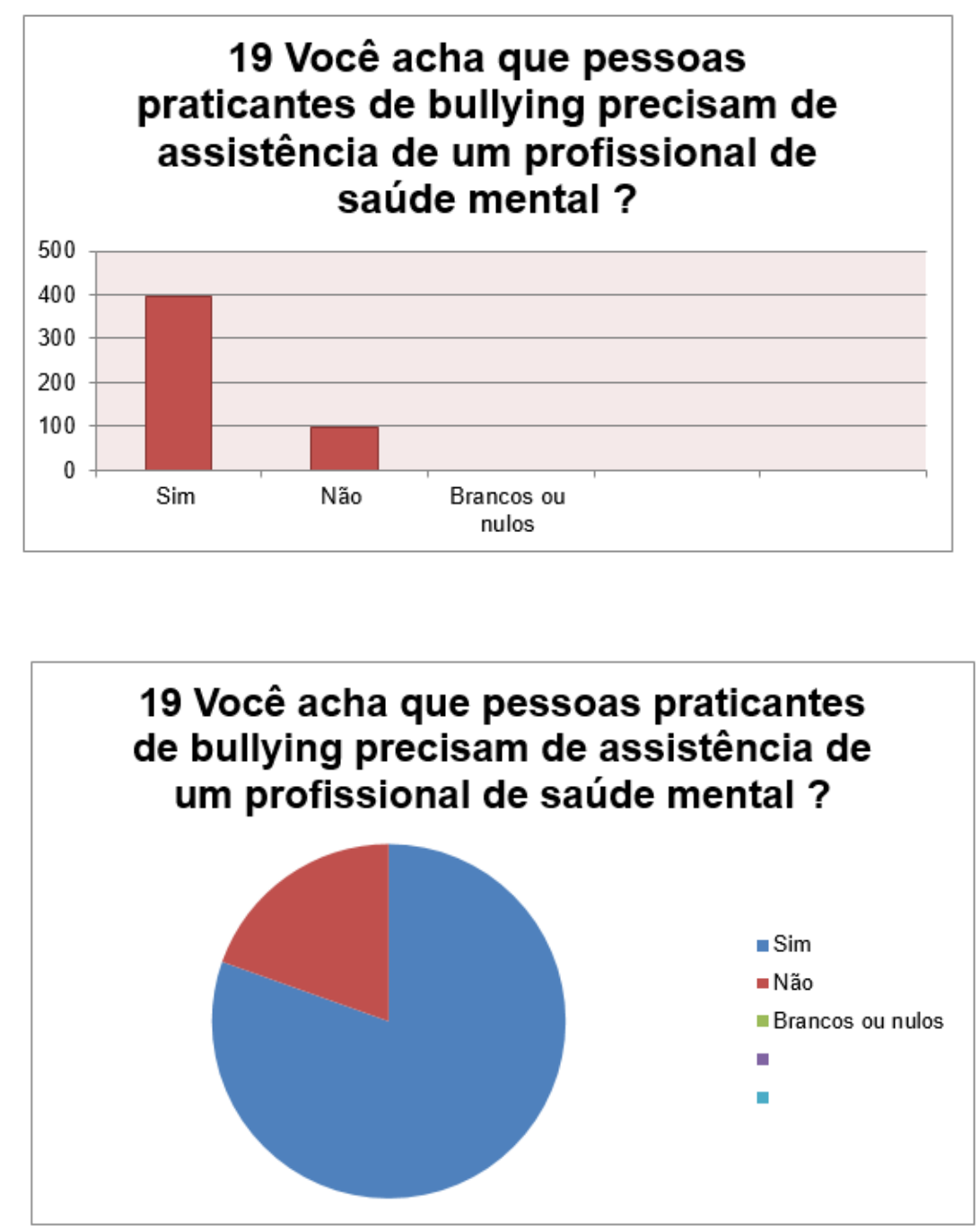

Figura 3.24: Você acha que pessoas praticantes de bullying precisam de assistência de um profissional de saúde mental ? 


\begin{tabular}{|l|l|l|l|l|}
\hline 20 & $\begin{array}{l}\text { E você, já praticou } \\
\text { bullying? }\end{array}$ & 177 & 316 & 0 \\
\hline
\end{tabular}

Tabela 3.20: E você, já praticou bullying ?
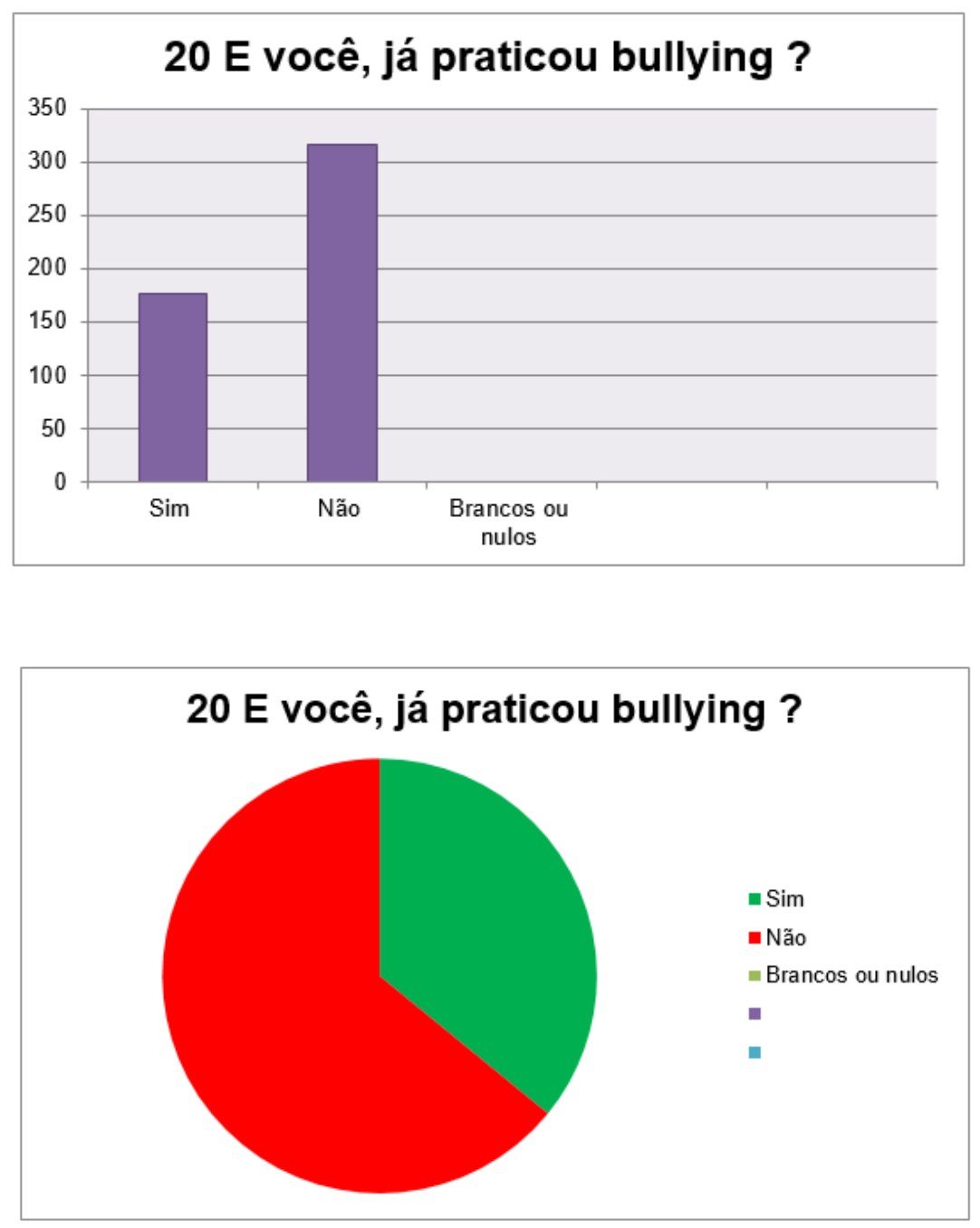

Figura 3.25: E você, já praticou bullying ? 
Cada grupo fez uma formatação diferente em seus gráficos, respeitando a orientação do professor para que fossem feitos dois gráficos, um de barra e outro de setores (pizza) para cada pergunta do trabalho. O professor mostrou que dependendo da pergunta haveria um gráfico mais adequado, sendo os mais utilizados estes confeccionados pelos alunos.

\subsection{Apresentação dos Trabalhos}

O momento da apresentação dos trabalhos foi ímpar para professor e alunos, seja pela ansiedade do momento, seja pelo trabalho prático exercido exclusivamente pelos alunos. Destacamos a dedicação e empenho de quase a totalidade dos alunos nesse projeto, discorreremos um pouco da apresentação sobre Bullying exemplificada até o momento.

Os alunos desta apresentação, assim como os outros, tomaram conta da aula, pedindo silêncio e atenção dos presentes. Foram seguros e enfáticos em cada pergunta comentando as discrepâncias encontradas. Todos os integrantes do grupo participaram em algum momento da apresentação tecendo seus próprios comentários.

Os grupos utilizaram, para a apresentação, Datashow, caixas de som e notebook como material eletroeletrônico e mostraram-se bastante natural com a utilização dos mesmos. Alguns grupos inovaram na apresentação simulando notícias em mídias, como por exemplo, o Jornal Nacional, outros prepararam apresentações em PowerPoint com efeitos sonoros e por último alguns grupos trouxeram notícias recentes a cerca do tema em forma de vídeos.

Foram surpreendentes as formas encontradas pelos alunos para apresentarem seus trabalhos.

Importante também foram as participações de vários alunos com questionamentos, críticas e sugestões aos trabalhos dos seus companheiros.

\subsection{Finalizando o trabalho com aulas sobre Medi- das de Tendência Central e Medidas de Dis- persão.}

Ainda de acordo com O PCN [2], dentre outras competências e habilidades a serem desenvolvidas em Matemática, destacamos, a competência M7 - Compreender o caráter aleatório e não-determinístico dos fenômenos naturais e sociais e utilizar instrumentos adequados para medidas e cálculos de probabilidade, para interpretar informações de variáveis apresentadas em uma distribuição estatística, as habilidades H27 - Calcular a média aritmética de um conjunto de dados expressos em uma tabela de 
frequências de dados agrupados (não em classes) ou gráficos de colunas e H29 - Utilizar médias aritméticas, noção de probabilidade ou conhecimentos estatísticos como recurso para a construção de argumentação.

Então o professor, após as apresentações, aproveita o momento para introduzir o conteúdo de Medidas de Tendência Central e Medidas de Dispersão, destacando as médias aritméticas simples e ponderadas, mediana, moda, variância e desvio padrão encontrados em cada trabalho e utilizando as próprias tabulações de cada tema, como dito anteriormente.

\subsubsection{Média Aritmética simples.}

Média aritmética simples $(\bar{x})$ dos valores $x_{1}, x_{2}, x_{3}, \ldots, x_{n}$ é o quociente entre a soma desses valores e a quantidade n (GIOVANNI [8], p. 544):

$$
\bar{x}=\frac{x_{1}+x_{2}+x_{3}+\cdots+x_{n}}{n}
$$

Exemplo 1: Quantos questionários, em média, cada componente do grupo havia aplicado? Obtivemos os seguintes resultados:

$$
\begin{aligned}
& 1^{\mathrm{o}} \text { componente - } 87 \\
& 2^{\mathrm{o}} \text { componente - } 115 \\
& 3^{\mathrm{o}} \text { componente - } 90 \\
& 4^{\mathrm{o}} \text { componente - } 98 \\
& 5^{\mathrm{o}} \text { componente - } 100
\end{aligned}
$$

$$
\bar{x}=\frac{87+115+90+98+100}{5}=98
$$

A média aritmética mostra que se todos os componentes tivessem aplicado a mesma quantidade de questionários, essa quantidade seria de 98 questionários.

Exemplo 2: Sabendo que os pesquisados conhecem 3 pessoas, 5 pessoas ou 8 pessoas que já sofreram bullyng. Pergunta-se, qual a média aritmética simples para o número de pessoas que já sofreram bullyng?

$$
\bar{x}=\frac{3+5+8}{3} \cong 5,33
$$




\subsubsection{Média ponderada.}

A média aritmética ponderada possibilita atribuir pesos ou importância diferentes a cada valor de uma amostra, podendo ser feita uma analogia com a média aritmética de elementos repetidos. A média ponderada facilita o cálculo de médias, quando há valores que se repetem várias vezes. Nesse caso, multiplicamos os valores pelo número de vezes (peso) em que eles ocorrem (GIOVANNI[8], p. 545):

$$
\bar{x}=\frac{x_{1} * f_{1}+x_{2} * f_{2}+x_{3} * f_{3}+\cdots+x_{n} * f_{n}}{f_{1}+f_{2}+f_{3}+\cdots+f_{n}}
$$

$\mathrm{ou}$

$$
\bar{x}=\frac{\sum_{i=1}^{i=n} x_{i} * f_{i}}{\sum_{i=1}^{i=n} f_{i}}
$$

Exemplo 3: Adaptando a pergunta 7 do questionário dos alunos. Conhece quantas pessoas que já sofreram bullyng?

Considerando que 189 pesquisados conhecem 3 pessoas que já sofreram bullyng, 78 pesquisados conhecem 5 pessoas que já sofreram bullyng e 35 pesquisados conhecem 8 pessoas que já sofreram bullyng, pergunta-se, quantas pessoas os pesquisados conhecem que já sofreram bullyng?

$$
\bar{x}=\frac{3 * 189+5 * 78+8 * 35}{189+78+35}=\frac{1237}{302} \cong 4,10
$$

Daí conclui-se que os pesquisados conhecem em média 4,10 pessoas que já sofreram bullyng.

\subsubsection{Média geométrica.}

Sejam $x_{1}, x_{2}, x_{3}, \ldots, x_{n}$, valores de $\mathrm{X}$, associados às frequências absolutas $f_{1}, f_{2}, f_{3}, \ldots, f_{n}$, respectivamente. A média geométrica de $\mathrm{X}$ é definida por:(FONSECA[6],P 102)

$$
\overline{M_{G}}=\sqrt[n]{x_{1}^{f_{1}} * x_{2}^{f_{2}} *_{3}^{f_{3}} * \cdots * x_{n}^{f_{n}}}
$$

Exemplo 4: Adaptando a pergunta 7 do questionário dos alunos. Conhece quantas pessoas que já sofreram bullyng?

Sabendo que os pesquisados conhecem 3 pessoas, 5 pessoas ou 8 pessoas que 
já sofreram bullyng. Pergunta-se, qual a média geométrica para o número de pessoas que já sofreram bullyng?

$$
\overline{M_{G}}=\sqrt[3]{3 * 5 * 8}=\sqrt[3]{120} \cong 4,93
$$

\subsubsection{Média harmônica.}

Sejam $x_{1}, x_{2}, x_{3}, \ldots, x_{n}$, valores de $\mathrm{X}$, associados às frequências absolutas $f_{1}, f_{2}, f_{3}, \ldots, f_{n}$, respectivamente. A média geométrica de $\mathrm{X}$ é definida por:(FONSECA[6],P 103)

$$
\overline{M_{H}}=\frac{n}{\frac{f_{1}}{x_{1}}+\frac{f_{2}}{x_{2}}+\frac{f_{3}}{x_{3}}+\cdots+\frac{f_{n}}{x_{n}}}
$$

Exemplo 5: Adaptando a pergunta 7 do questionário dos alunos. Conhece quantas pessoas que já sofreram bullyng?

Sabendo que os pesquisados conhecem 3 pessoas, 5 pessoas ou 8 pessoas que já sofreram bullyng. Pergunta-se, qual a média harmônica para o número de pessoas que já sofreram bullyng?

$$
\overline{M_{H}}=\frac{3}{\frac{1}{3}+\frac{1}{5}+\frac{1}{8}}=\frac{3}{\frac{79}{120}} \cong 4,04
$$

Vale ressaltar que:

$$
\overline{M_{H}} \leq \overline{M_{G}} \leq \bar{x}
$$

Ou seja, a média harmônica é menor ou igual à média geométrica que é menor ou igual à media aritmética para uma mesma amostra de elementos. Estas médias só serão iguais se todos os elementos da amostra forem iguais.

Exemplo 6: Calcule as médias aritmética, geométrica e harmônica da amostra $(4,4,4)$

$$
\begin{gathered}
\bar{x}=\frac{4+4+4}{4}=4 \\
\overline{M_{G}}=\sqrt[3]{4 * 4 * 4}=\sqrt[3]{64}=4
\end{gathered}
$$




$$
\overline{M_{H}}=\frac{3}{\frac{1}{4}+\frac{1}{4}+\frac{1}{4}}=\frac{3}{\frac{3}{4}}=4
$$

\subsubsection{Mediana.}

O valor que ocupa a posição central de um conjunto de valores, colocados em ordem crescente ou decrescente de grandeza, é chamado mediana. Se a distribuição tiver um número par de dados, não existe um valor central, mas dois valores centrais. Nesse caso, a mediana é a média aritmética dos dois valores centrais.(GIOVANNI[8], p. 547)

\subsubsection{Moda.}

Moda de um conjunto de valores é o valor que aparece um maior número de vezes, ou seja, é o valor de maior frequência absoluta. (GIOVANNI[8], p. 548)

\subsubsection{Desvio médio.}

A diferença entre cada uma dos valores e a média de uma amostra é chamada de desvio para a média, $\left(x_{i}-\bar{x}\right)$. A média aritmética dos valores absolutos dos desvios para a média é uma medida de dispersão chamada desvio médio, que se indica $d_{m}$. (GIOVANNI[8], p. 551)

$$
d_{m}=\frac{\sum_{i=1}^{i=n}\left|x_{i}-\bar{x}\right|}{n}=\frac{\left|x_{1}-\bar{x}\right|+\left|x_{2}-\bar{x}\right|+\left|x_{3}-\bar{x}\right|+\cdots+\left|x_{n}-\bar{x}\right|}{n}
$$

Exemplo 7: Sabendo que os pesquisados conhecem 3 pessoas, 5 pessoas ou 8 pessoas que já sofreram bullyng. Pergunta-se, qual o desvio médio para esta amostra?

$$
d_{m}=\frac{|3-5,33|+|5-5,33|+|8-5,33|}{3} \cong 1,78
$$

\subsubsection{Variância.}

O valor que corresponde à média aritmética dos quadrados dos desvios em relação à media recebe o nome de variância, valor esse que se indica por $V_{a}$. (GIOVANNI[8], p.553) 


$$
V_{a}=\frac{\sum_{i=1}^{i=n} f_{i}\left(x_{i}-\bar{x}\right)^{2}}{\sum_{i=1}^{i=n} f_{i}}=\frac{f_{1}\left(x_{1}-\bar{x}\right)^{2}+f_{2}\left(x_{2}-\bar{x}\right)^{2}+f_{3}\left(x_{3}-\bar{x}\right)^{2}+\cdots+f_{n}\left(x_{n}-\bar{x}\right)^{2}}{f_{1}+f_{2}+f_{3}+\cdots+f_{n}}
$$

Exemplo 8: Sabendo que os pesquisados conhecem 3 pessoas, 5 pessoas ou 8 pessoas que já sofreram bullyng. Pergunta-se, qual a variância desta amostra?

$$
V_{a}=\frac{(3-5,33)^{2}+(5-5,33)^{2}+(8-5,33)^{2}}{3} \cong 4,22
$$

\subsubsection{Desvio padrão.}

A raiz quadrada da variância chama-se desvio padrão do conjunto de dados, valor que representamos por $S$. (GIOVANNI[8], p. 553).

O desvio padrão mostra o quanto uma amostra é homogênea ou heterogênea, pois quanto menor for o desvio padrão, mais homogênea será a amostra e vice-versa.

$$
S=\sqrt{V_{a}}
$$

Exemplo 9: Sabendo que os pesquisados conhecem 3 pessoas, 5 pessoas ou 8 pessoas que já sofreram bullyng. Pergunta-se, qual o desvio padrão desta amostra?

$$
s=\sqrt{4,22} \cong 2,05
$$

\subsection{Avaliação sem trauma}

Buscando novos caminhos para melhor aprendizagem utilizamos este projeto da prática da matemática através da estatística. Sendo assim, também é natural buscarmos novas formas de avaliação que contemple a ênfase no aprender.

Se nossos alunos participaram, como protagonistas, desde o início deste projeto, eles são os mais indicados em fornecer a métrica avaliativa para cada grupo e para cada aluno individualmente. Sugerimos que cada grupo destaque os pontos fortes e fracos de si e dos outros, inclusive com crítica e sugestões de melhorias em forma de relatório, mesmo sem saber eles estarão fornecendo subsídios para que o professor formule a nota de cada grupo. Sem provocar constrangimento os alunos contribuirão 
também no momento avaliativo. Ao professor fica reservado complementar as avaliações que o mesmo observou durante todo o processo.

Desse modo o aluno iniciou e encerrou o projeto, desde sua concepção até a sua avaliação. 


\section{Capítulo 4}

\section{CONSIDERAÇÕES FINAIS}

Esse trabalho foi desenvolvido, seguindo orientações dos Parâmetros Curriculares Nacionais [2], dentre outras bibliografias e, principalmente, a partir de levantamentos realizados pelos próprios alunos na comunidade escolar. Estes por sua vez apresentaram-se bastantes interessados, pois estavam analisando dados reais levantados a partir de questionários e gráficos elaborados por eles mesmos. Deste trabalho, surgiram informações que nos permitem afirmar que o ensino de estatística de forma tradicional é precário no contexto escolar.

Nesse contexto, os profissionais em educação precisam entender que ao transformar os alunos em protagonistas de seu aprendizado consegue-se resultados muito melhores. Estatística atualmente é fundamental para o cidadão, pois permite interpretar e entender o mundo em que vive, compreendendo notícias vinculadas pelos meios de comunicação, livros e outras fontes. Além disso, esse é um campo de estudo que utiliza uma quantidade muito grande de outros conteúdos matemáticos, permitindo, dessa forma, compreender, criticar, aplicar conceitos e procedimentos, e ainda, facilitar tomadas de decisões diante de certas situações problemas.

Entendemos, que o trabalho com Estatística, isto é, a coleta, a organização, a interpretação e a análise de dados, não é tão fácil como se pensa. Ela requer estudo e conhecimento não só matemático como também das regras de formação dos modos de representação e os aspectos cognitivos envolvidos por tal trabalho. Por isso, o trabalho com esses modos de representação deve ser proposto de maneira simples e a mais objetiva possível, fazendo com que o aluno seja estimulado a fazer perguntas, estabelecer relações, construir justificativas e desenvolver o espírito de investigação.

Mediante a análise dos resultados obtidos em sala de aula, podemos concluir que estudar estatística a partir dos dados coletados pelos próprios alunos, isso traz uma significativa contribuição para o trabalho do professor, aprendizado do aluno e para a educação de um modo geral.

Sendo assim o professor precisa desenvolver uma prática pedagógica, na qual sejam propostas situações em que os alunos desenvolvam atividades, observando e 
construindo os eventos possíveis, através de experiências concretas. Assim, a aprendizagem da matemática com atividades de Estatísticas, complementará a formação dos alunos de forma significativa considerando-se situações familiares a eles, situações que sejam contextualizadas, investigadas e analisadas, a fim de garantir a possibilidade de desenvolvimento de uma visão estatística e probabilística expressiva.

O professor é o facilitador do diálogo entre o aluno e o conhecimento, e não o seu obstáculo, ele tem o papel fundamental em estimular o aluno a ser pesquisador, ter autonomia, ser crítico, ser o construtor e o reconstrutor de seu próprio conhecimento. Deve perceber a diferença entre o seu conhecimento e o do aluno, visto que o trabalho educativo caminha na direção da diminuição gradativa dessa diferença.

Ensinar é ter uma proposta clara do trabalho pedagógico, é propor, não impor, é promover o debate, não o embate. 


\section{REFERÊNCIAS}

[1] BECKER, F., A Epistemologia do Professor: o cotidiano da escola. Petrópolis: Vozes, (1993).

[2] BRASIL. Secretaria de Educação Fundamental. Parâmetros Curriculares Nacionais Ensino Médio: Matemática/Secretaria de Educação Média e Tecnológica. Parte III - Ciências da Natureza, Matemática e suas Tecnologias. Disponível em: http://portal.mec.gov.br/seb/arquivos/pdf/ciencian.pdf. Acesso em 13 de abril de 2016

[3] CARvalho, A. M. F. T. de; SAViOli, A. M. P. das D. Demonstrações em matemática na educação matemática no ensino superior. In: FROTA, M. C. R.; BIAnCHINI, B. L.; CARvAlHO, A. M. F. T. (Org.) Marcas da educação matemática no ensino superior. Campinas/SP: Papirus, 367p. (Coleção Perspectivas em Educação Matemática), 2013.

[4] COHEN, A. R.; FINK, L. Comportamento organizacional: conceitos e estudos de caso. 7. ed. Rio de Janeiro: Campus, p.651, 2003.

[5] DESAFIOS do trabalho em equipe. Direção: Luís Almeida Marins filho. São Paulo: Commit, [200-]. 1 Fita vídeo (20min.), VHS, son., color. GIL, Antonio Carlos. Como elaborar projetos de pesquisa. São Paulo: Atlas, 1991.

[6] FOnSECA, J. S. Da, GILBERTO, de A. M. Curso de estatística - 3.ed. - São Paulo: Atlas, 1982

[7] GIL, A. C. Como elaborar projetos de pesquisa. São Paulo: Atlas, 2002.

[8] GIOVANNI, J. R., 1937 - Matemática Fundamental: uma nova abordagem: ensino médio: volume único / José Ruy Giovanni, José Roberto Bonjorno, José Ruy Giovanni Jr. - São Paulo: FTD, 2002.

[9] LAKATOS, E. M., MARCONI, M. A. Fundamentos de metodologia científica. São Paulo: Atlas, 2003. 
[10] LEVIN, J. Estatística aplicada a ciências humanas. 2. Ed. São Paulo: Harbra, 1987.

[11] LUDKE, M. \& ANDRÉ, M. E. D. A. Pesquisa em educação: abordagens qualitativas. São Paulo, Editora Pedagógica e Universitária, 1986.

[12] MACHADO, N J. Mateologia, zero. Matemática dez. Revista Pátio. Ano XII, p.13-15, ago/out 2008.

[13] PERREnOUd, P. , Dez novas competências para ensinar. Porto Alegre: ArtMed,(2000).

[14] SILVA, E. L.; MENEZES, E. M. Metodologia da pesquisa e elaboração de dissertação. Florianópolis. Laboratório de Ensino à Distância da UFSC, 2000.

[15] UNIVERSIDADE FEDERAL DO RIO GRANDE DO SUL. Instituto de Matemática, Estatística, História da Estatística, Rio Grande do Sul, disponível em: ¡http://www.ufrgs.br/mat/graduacao/estatistica/historia-daestatisticą: acesso em 13 de abril de 2016.

[16] VASCONCELLOS, C. S., "Alguns (di)lemas do professor no contexto da complexidade". Pátio, n.27, ano VII, Porto Alegre, p.12-15, ago-out. (2003). 